OPEN ACCESS

Edited by:

Hirokazu Toju,

Kyoto University, Japan

Reviewed by:

Narayan Chandra Paul,

Chonnam National University,

South Korea

Jian Xin Deng,

Yangtze University, China

*Correspondence:

Mei Luo

08/uomei@163.com

Specialty section:

This article was submitted to

Microbial Symbioses,

a section of the journa

Frontiers in Microbiology

Received: 23 September 2020 Accepted: 29 December 2020

Published: 09 February 2021

Citation:

Dong Z, Manawasinghe IS,

Huang Y, Shu Y, Phillips AJL,

Dissanayake AJ, Hyde KD, Xiang M

and Luo M (2021) Endophytic

Diaporthe Associated With Citrus

grandis cv. Tomentosa in China.

Front. Microbiol. 11:609387.

doi: 10.3389/fmicb.2020.609387

\section{Endophytic Diaporthe Associated With Citrus grandis cv. Tomentosa in China}

\author{
Zhangyong Dong ${ }^{1}$, Ishara S. Manawasinghe 1,2, Yinghua Huang ${ }^{1}$, Yongxin Shu', \\ Alan J. L. Phillips ${ }^{3}$, Asha J. Dissanayake ${ }^{4}$, Kevin D. Hyde ${ }^{1,2}$, Meimei Xiang ${ }^{1}$ and Mei Luo ${ }^{1 *}$ \\ ${ }^{1}$ Innovative Institute for Plant Health, Zhongkai University of Agriculture and Engineering, Guangzhou, China, ${ }^{2}$ Center \\ of Excellence in Fungal Research, Mae Fah Luang University, Mueang Chiang Rai, Thailand, ${ }^{3}$ Faculdade de Ciências, \\ Biosystems and Integrative Sciences Institute (Bio/SI), Universidade de Lisboa, Lisbon, Portugal, ${ }^{4}$ School of Life Sciences \\ and Technology, University of Electronic Science and Technology of China, Chengdu, China
}

Diaporthe species are associated with Citrus as endophytes, pathogens, and saprobes worldwide. However, little is known about Diaporthe as endophytes in Citrus grandis in China. In this study, 24 endophytic Diaporthe isolates were obtained from cultivated C. grandis cv. "Tomentosa" in Huazhou, Guangdong Province in 2019. The nuclear ribosomal internal transcribed spacer (ITS), partial sequences of translation elongation factor 1- $\alpha$ (tef1), $\beta$-tubulin (tub2), and partial calmodulin (cal) gene regions were sequenced and employed to construct phylogenetic trees. Based on morphology and combined multigene phylogeny, eleven Diaporthe species were identified including two new species, Diaporthe endocitricola and $D$. guangdongensis. These are the first report of $D$. apiculata, $D$. aquatica, $D$. arecae, $D$. biconispora, $D$. limonicola, $D$. masirevicii, $D$. passifloricola, $D$. perseae, and $D$. sennae on $C$. grandis. This study provides the first intensive study of endophytic Diaporthe species on C. grandis cv. tomentosa in China. These results will improve the current knowledge of Diaporthe species associated with C. grandis. The results obtained in this study will also help to understand the potential pathogens and biocontrol agents and to develop a platform in disease management.

Keywords: nine new host records, two new species, Diaporthales, phylogeny, taxonomy

\section{INTRODUCTION}

Diaporthe Nitschke (1870) belongs to Diaporthaceae (Senanayake et al., 2017) which comprises plant pathogens, endophytes, and saprobes (Udayanga et al., 2011; Huang et al., 2013, 2015). In earlier studies, the classification of Diaporthe depended mainly on morphology, culture characteristics, and host affiliations (Udayanga et al., 2011). However, with the development of molecular methods, species identification based on multigene phylogeny together with morphological characters provided a more accurate identification (Udayanga et al., 2011; Gao et al., 2017). In recent studies, ITS, tef1, tub2, cal, and partial histone (HIS) genes have been used for species delimitation in this genus (Udayanga et al., 2014a; Santos et al., 2017; Guarnaccia and Crous, 2018; Manawasinghe et al., 2019). Diaporthe species have 
a worldwide distribution and diverse host associations (Udayanga et al., 2014b). More than one Diaporthe species have been reported on a single host (Guarnaccia and Crous, 2018; Manawasinghe et al., 2019) and one species can be associated with more than one host in the same country or region (Santos and Phillips, 2009; Diogo et al., 2010; Guarnaccia et al., 2018b; Manawasinghe et al., 2019).

Diaporthe species are well-known pathogens on economically important crops and woody hosts (Udayanga et al., 2011) and many of these diseases were previously known as "Phomopsis diseases." Rossman et al. (2014) proposed that the genus name Diaporthe should take priority over Phomopsis. Diaporthe species are widely associated with blights, cankers, diebacks, melanose, and stem-end rots (Udayanga et al., 2014b; Guarnaccia and Crous, 2017; Manawasinghe et al., 2019). There are 19 Diaporthe species associated with soybean (Glycine max L.) and several of them cause leaf and pod blights and seed decay (Udayanga et al., 2014b; Farr and Rossman, 2020). Diaporthe species have been recorded causing leaf spots on Camellia spp. (Gao et al., 2016, 2017; Guarnaccia and Crous, 2018). On Citrus spp. these taxa have been reported to cause melanosis, stem-end rot, and gummosis (Mondal et al., 2007; Udayanga et al., 2014a; Guarnaccia and Crous, 2017, 2018). The causal organism of sunflower stem canker D. helianthi can cause yield loss of up to $40 \%$ in Europe and United States (Thompson et al., 2011). Diaporthe species are associated with Phomopsis cane and leaf spot on grapevine worldwide (Guarnaccia and Crous, 2018; Manawasinghe et al., 2019). Worldwide, 27 Diaporthe species have been reported on grapevines and each species and species combination develop different symptoms (Manawasinghe et al., 2019). Moreover, Diaporthe also associated as endophytes on grapevines (Guarnaccia and Crous, 2018).

In China, Diaporthe species have been reported as pathogens causing blights, dieback, scab, stem-end rots and trunk diseases in different hosts such as, Camellia (Gao et al., 2017), Citrus (Huang et al., 2013), Coffea (Gao et al., 2017), Elaeagnus (Gao et al., 2017), Lithocarpus (Gao et al., 2017), Senna (Yang et al., 2017a), and Vitis (Dissanayake et al., 2015; Manawasinghe et al., 2019). Furthermore, Diaporthe species have been reported as saprobes on dead plants and as freshwater fungi ( $\mathrm{Hu}$ et al., 2012; Huang et al., 2013). Huang et al. (2015) identified 16 Diaporthe species including seven new Diaporthe species from Citrus, adding evidence to the endophytic species richness of Diaporthe in Citrus plants. Although there are several studies on Diaporthe associated with Citrus (Huang et al., 2013; Guarnaccia and Crous, 2017), the endophytic fungi associated with C. grandis and their relationships with the plant are unknown.

Diaporthe species are often reported as endophytes (Murali et al., 2006; Botella and Diez, 2011; Huang et al., 2015) and they may provide several advantages to the plants. They possibly contribute to resistance against pathogens and might also act as a secondary defence layer of the associated plant (Hyde and Soytong, 2008; Dini-Andreote, 2020). It is important to explore the relationship between natural products from the plant and its endophytes (Alvin et al., 2014) since this might reveal novel compounds with antimicrobial activities and medicinal properties. The objectives of the present study were to isolate and identify endophytic Diaporthe species associated with healthy C. grandis cv. "Tomentosa" trees collected in Huazhou, Guangdong, China. Detailed descriptions of novel species identified based on molecular phylogeny and morphology are provided.

\section{MATERIALS AND METHODS}

\section{Sampling and Isolation of Endophytic Fungi}

Healthy C. grandis cv. "Tomentosa" leaves, twigs, and fruits were collected randomly from a Citrus orchard in Huazhou city, Guangdong Province, China in May 2019. Samples were placed in plastic zip-lock bags containing sterilized wet cotton to prevent drying, taken to the laboratory and isolations were made on the same day. The samples were initially washed with tap water and then with sterile water. The leaves were then cut into $3 \mathrm{~mm} \times 3 \mathrm{~mm}$ segments, twigs into pieces $3 \mathrm{~mm}$ long, and the fruits into $3 \mathrm{~cm}^{3}$ cubes. Each piece was surface sterilized by dipping sequentially into $75 \%$ ethanol for $40 \mathrm{~s}, 2.5 \% \mathrm{NaOCl}$ (sodium hypochlorite) for $90 \mathrm{~s}$, rinsed with three changes of sterile water, dried on sterilized filter paper and then placed on potato dextrose agar (PDA). Plates were incubated at $25^{\circ} \mathrm{C}$ with $12 \mathrm{~h}$ dark and $12 \mathrm{~h}$ fluorescent light. In total, 80 tissue segments were obtained from leaves, twigs, and fruits. Fungi growing from the edges of the tissue were sub-cultured on fresh PDA plates. To obtain pure cultures, single spore isolation was carried out (Chomnunti et al., 2011).

\section{DNA Extraction and PCR Amplification}

Mycelia were scraped from 7 days old pure cultures growing on PDA and total genomic DNA was extracted using the CTAB method (Sun et al., 2009). The ITS region was amplified and sequenced with primers ITS1/ITS4 (White et al., 1990). BLAST searches in GenBank with the ITS sequences provided genus level identifications. Once the BLAST results confirmed the isolates as Diaporthe species, additional three gene regions, namely translation elongation factor-1 $\alpha$ (tef1), $\beta$-tubulin (tub2), and calmodulin (cal) were amplified and sequenced. The protocols for PCR amplification were followed as given in Udayanga et al. (2012) and Manawasinghe et al. (2019). The primer pairs and their respective amplification conditions are given in Table 1. Positive PCR amplicons were observed on $1 \%$ agarose electrophoresis gel. Sequencing (forward direction, both directions when necessary) was done by Tianyi Huiyuan Biotechnology Co., Ltd., Guangzhou, China. Initial sequence quality was checked with BioEdit 7.25 (Hall, 2006). All sequence data generated in this study were submitted to GenBank (Supplementary Table 1).

\section{Phylogenetic Analysis}

For the phylogenetic analysis, sequences of reference Diaporthe species and related taxa were obtained from NCBI GenBank 
TABLE 1 | Gene regions and respective primer pairs used in the study.

\begin{tabular}{|c|c|c|c|c|}
\hline Gene region & Primers & Sequence $5^{\prime}-3^{\prime}$ & Optimized PCR protocols & References \\
\hline \multirow[t]{2}{*}{ ITS } & ITS1 & TCCGTAGGTGAACCTGCGG & \multirow{2}{*}{$\begin{array}{l}94^{\circ} \mathrm{C}: 5 \mathrm{~min},\left(94^{\circ} \mathrm{C}: 30 \mathrm{~s}, 55^{\circ} \mathrm{C}: 50 \mathrm{~s}, 72^{\circ} \mathrm{C}:\right. \\
1 \mathrm{~min}) \times 34 \text { cycles } 72^{\circ} \mathrm{C}: 10 \mathrm{~min}\end{array}$} & \multirow[t]{2}{*}{ White et al., 1990} \\
\hline & ITS4 & TCCTCCGCTTATTGATATGC & & \\
\hline \multirow[t]{2}{*}{ tub2 } & BT2a & GGTAACCAAATCGGTGCTGCTIT & \multirow{2}{*}{$\begin{array}{l}94^{\circ} \mathrm{C}: 5 \mathrm{~min},\left(94^{\circ} \mathrm{C}: 30 \mathrm{~s}, 58^{\circ} \mathrm{C}: 50 \mathrm{~s}, 72^{\circ} \mathrm{C} \text { : }\right. \\
1 \mathrm{~min}) \times 34 \text { cycles } 72^{\circ} \mathrm{C}: 10 \mathrm{~min}\end{array}$} & \multirow[t]{2}{*}{ Glass and Donaldson, 1995} \\
\hline & $\mathrm{Bt} 2 \mathrm{~b}$ & ACCCTCAGTGTAGTGACCCTTGGC & & \\
\hline \multirow[t]{2}{*}{ tef1 } & EF1-728F & CATCGAGAAGTTCGAGAAGG & \multirow{2}{*}{$\begin{array}{l}95^{\circ} \mathrm{C}: 5 \mathrm{~min},\left(95^{\circ} \mathrm{C}: 30 \mathrm{~s}, 58^{\circ} \mathrm{C}: 30 \mathrm{~s}, 72^{\circ} \mathrm{C} \text { : }\right. \\
1 \mathrm{~min}) \times 34 \text { cycles } 72^{\circ} \mathrm{C}: 10 \mathrm{~min}\end{array}$} & \multirow[t]{2}{*}{ Carbone and Kohn, 1999} \\
\hline & EF1-986R & TACTTGAAGGAACCCTTACC & & \\
\hline \multirow[t]{2}{*}{ cal } & CAL-228F & GAGTTCAAGGAGGCCTTCTCCC & \multirow{2}{*}{$\begin{array}{l}95^{\circ} \mathrm{C}: 5 \mathrm{~min},\left(95^{\circ} \mathrm{C}: 30 \mathrm{~s}, 55^{\circ} \mathrm{C}: 50 \mathrm{~s}, 72^{\circ} \mathrm{C}:\right. \\
1 \mathrm{~min}) \times 34 \text { cycles } 72^{\circ} \mathrm{C}: 10 \mathrm{~min}\end{array}$} & \multirow[t]{2}{*}{ Carbone and Kohn, 1999} \\
\hline & CAL-737R & CATCTTCTGGCCATCATGG & & \\
\hline
\end{tabular}

and selected by reference to relevant published trees (Guarnaccia et al., 2018b; Yang et al., 2018a; Hyde et al., 2019; Long et al., 2019; Manawasinghe et al., 2019; Supplementary Table 1). Sequences for each locus were aligned together with the sequences obtained in the present study using MAFFT (Katoh and Toh, 2010) ${ }^{1}$. Alignments were checked and manually adjusted where necessary with BioEdit v. 5 (Hall, 2006). Phylogenetic analyses were conducted by maximum likelihood (ML) in RAxML (Silvestro and Michalak, 2010), maximum parsimony (MP) in PAUP (v4.0) (Swofford, 2003) and Bayesian analyses (BI) in MrBayes (v. 3.0b4) (Ronquist and Huelsenbeck, 2003). The final analysis was made with the concatenated data set of ITS, tef1, tub2, cal following Dissanayake et al. (2017a); Guarnaccia et al. (2018b) and Manawasinghe et al. (2019).

For the MP analysis, ambiguous regions in the alignment were excluded and gaps were treated as missing data. Tree stability was evaluated with 1,000 bootstrap replications. Zerolength branches were collapsed, and all parsimonious trees were saved. Tree parameters; tree-length (TL), consistency index $(\mathrm{CI})$, retention index (RI), relative consistency index (RC), and homoplasy index (HI) were calculated. Kishino-Hasegawa tests (KHT) were conducted to evaluate differences between the trees inferred under different optimality criteria (Kishino and Hasegawa, 1989). MrModeltest v. 2.3 (Nylander, 2004) was used to determine the evolutionary models for each locus to be used in Bayesian and maximum likelihood analyses. The maximum likelihood analyses were conducted using RAxML-HPC2 on XSEDE (8.2.8) (Stamatakis, 2014) in the CIPRES Science Gateway platform (Miller et al., 2010). The GTR + I + G evolutionary model was employed with 1,000 non-parametric bootstrapping iterations. Bayesian analysis was performed in MrBayes v. 3.0b4 (Ronquist and Huelsenbeck, 2003). Six simultaneous markov chains were run for $10^{6}$ generations, sampling the trees at every 200 th generation. From the 5,000 trees obtained, the first 2,000 representing the burn-in phase were discarded. The remaining 3,000 trees were used to calculate posterior probabilities (BYPPs) in a majority rule consensus tree. The final sequence alignment generated in this study was submitted to TreeBASE ID $26384^{2}$. Taxonomic novelties were submitted to Index Fungorum ${ }^{3}$ and

\footnotetext{
${ }^{1}$ http://www.ebi.ac.uk/Tools/msa/mafft/

${ }^{2}$ http://purl.org/phylo/treebase/phylows/study/TB2:S26384? $\mathrm{x}$-access-code= e34e24939299e00766a5bf45970dabb0\&format $=\mathrm{html}$

${ }^{3}$ www.indexfungorum.org
}

Faces of Fungi database (Jayasiri et al., 2015). Newly generated sequences were deposited in GenBank.

\section{Morphological Characterization}

Agar plugs (5mm diam) were taken from actively growing cultures on PDA and transferred onto PDA, malt extract agar (MEA) (Crous et al., 2009) and pine needle agar (PNA: 2\% WA with three sterilized pine needles) (Smith et al., 1996) plates and incubated at $25^{\circ} \mathrm{C}$ with 12 hours of alternating darkness and fluorescent light per day for over a month to induce sporulation (Gomes et al., 2013; Huang et al., 2015). Colony characters and pigmentation on MEA and PDA were recorded after 7, 15, and 30 days. Colony color (upper and reverse) was described by referring to the color charts of Rayner (1970). Colony diameters were measured after 3-7 days. Digital images of morphological structures (shape, size, and color) were recorded with an Eclipse $80 \mathrm{i}$ photographic microscope (Nikon, Japan). Conidial length and width were measured for 40 conidia per isolate using NISElements BR 3.2, and the mean values were calculated with their standard deviations (SDs).

\section{RESULTS}

In total 24 endophytic Diaporthe strains were obtained (two from leaves, five from twigs and 17 from fruits). The phylogenetic analysis of a combined ITS, tef1, tub2, and cal sequence alignment was conducted using 222 Diaporthe strains (including type strains). The phylogenetic tree was rooted with Diaporthella corylina (CBS 121124). The final ML tree topology was similar to the MP and BI trees. The best scoring ML tree with a final likelihood value of -55258.653244 is given in Figure 1. The matrix consisted of 1,567 distinct alignment patterns, with $32.05 \%$ of undetermined characters or gaps. Estimated base frequencies were as follows: $\mathrm{A}=0.215752$, $\mathrm{C}=0.315593, \mathrm{G}=0.242350, \mathrm{~T}=0.226306$; substitution rates $\mathrm{AC}=1.197240, \mathrm{AG}=3.454524, \mathrm{AT}=1.225071, \mathrm{CG}=0.944927$, $\mathrm{CT}=4.809973, \mathrm{GT}=1.000000 ;$ gamma distribution shape parameter $\alpha=0.511913$. The dataset consisted of 2,134 characters with 779 constant characters and 1,072 parsimonyinformative and 283 parsimony-uninformative characters. The maximum number of trees generated was 5,000, and the most parsimonious trees had a length of 10930 steps $(C I=0.252$, $\mathrm{RI}=0.731, \mathrm{RC}=0.184, \mathrm{HI}=0.748)$. In the $\mathrm{ML}$ tree, isolates from this study clustered together with nine known 


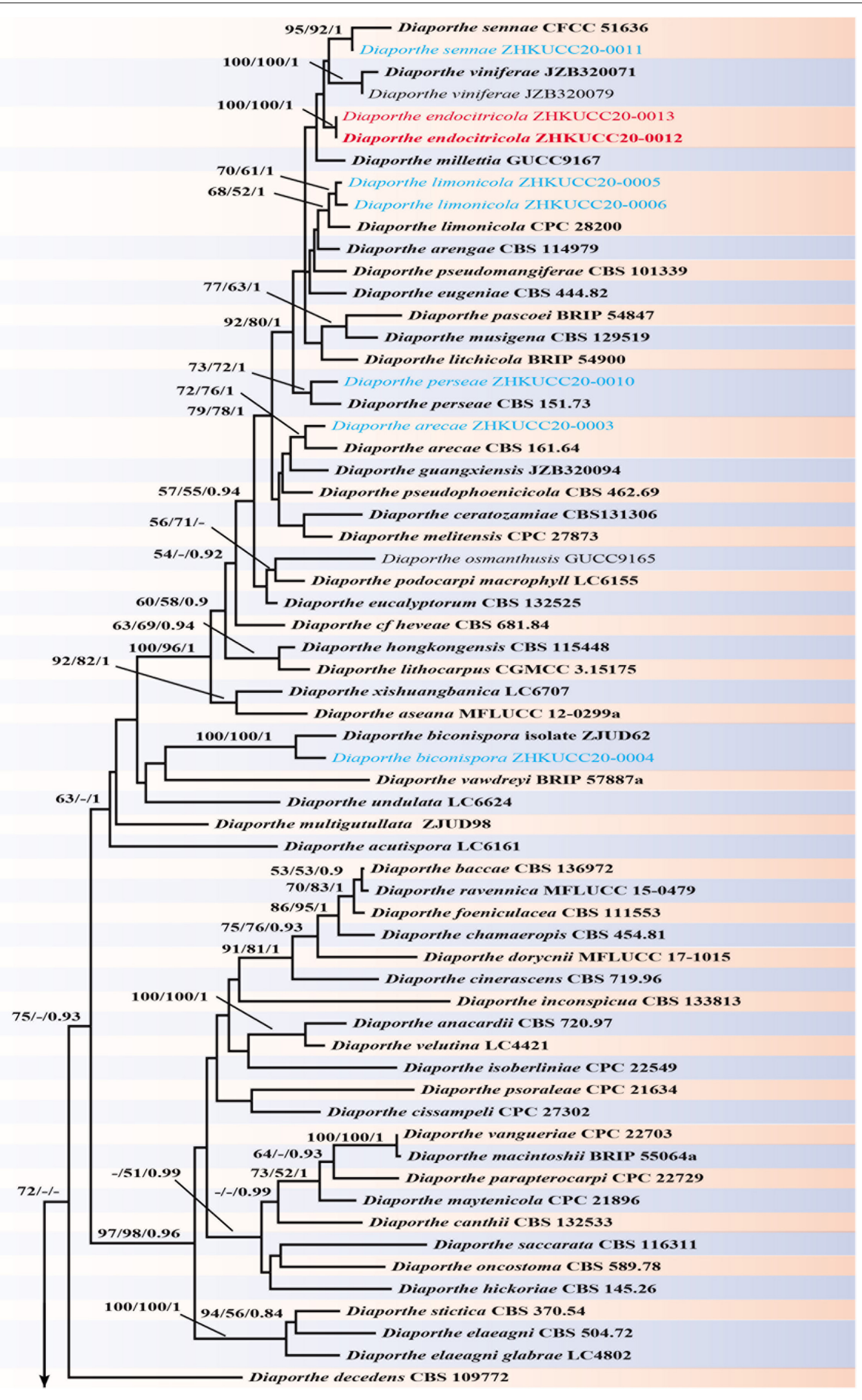

FIGURE 1 | Continued 


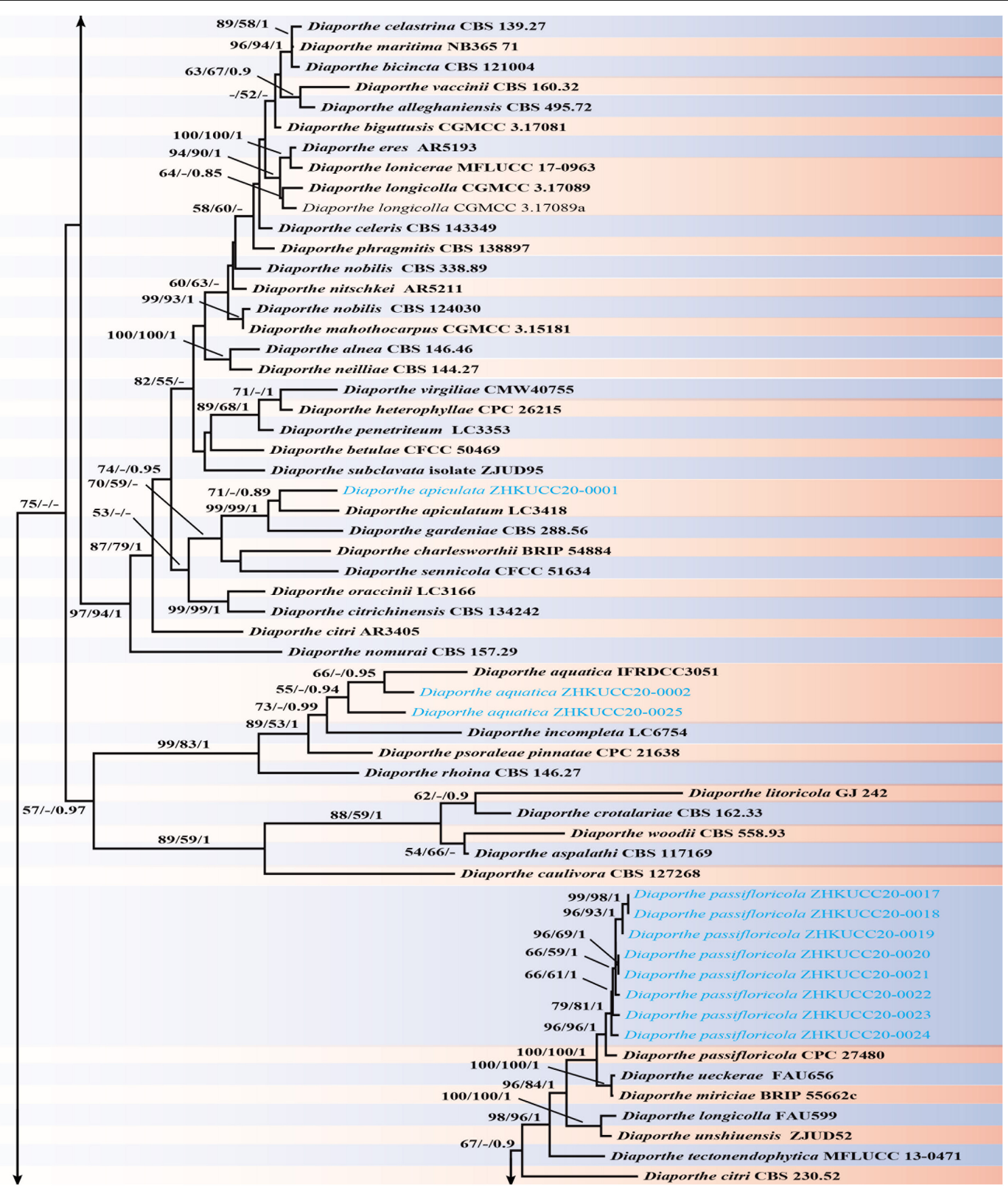

FIGURE 1 | Continued

Diaporthe species and as two novel phylogenetic lineages. Species descriptions and illustrations of all these species are given below.

\section{Taxonomy}

\section{Diaporthe apiculata}

Y.H. Gao and L. Cai, Syst Biodivers 14: 106 (2016) Index Fungorum number: 811217, Faces of fungi Number: FoF 08403 (Figure 2).
Endophytic on C. grandis "Tomentosa" twigs. Sexual morph: not observed. Asexual morph: Pycnidia $140-490 \mu \mathrm{m} \times 130$ $450 \mu \mathrm{m}(\bar{x}=377 \mu \mathrm{m} \times 303 \mu \mathrm{m})$, hemispherical, erumpent, coated with white aerial mycelium. Conidiophores 10$22 \mu \mathrm{m} \times 1-2 \mu \mathrm{m}(\bar{x}=15 \pm 3.5 \mu \mathrm{m} \times 2 \pm 0.3 \mu \mathrm{m})$, subcylindrical, unbranched, densely aggregated, straight to sinuous. Alpha conidia $6-8 \mu \mathrm{m} \quad \times \quad 2-3 \mu \mathrm{m}$ $(\bar{x}=7 \pm 0.7 \mu \mathrm{m} \times 3 \pm 0.3 \mu \mathrm{m})$, cylindrical to ellipsoid, hyaline, aseptate, biguttulate or three to four guttules. Beta conidia 
19-31 $\mu \mathrm{m} \times 1-2 \mu \mathrm{m}(\bar{x}=26 \pm 3 \mu \mathrm{m} \times 2 \pm 0.2 \mu \mathrm{m})$, filiform, hyaline, and tapering toward both ends, hamate or curved.

Culture Characteristics: Colonies on PDA reach $75 \mathrm{~mm}$ diam. after 5 days at $25^{\circ} \mathrm{C}$. White fluffy aerial mycelium, margin filiform. Later turning to brownish yellow, pigmentation developing from the center. Reverse initially white and then turning brownish-yellow from the center, some became brownish-green.

Material examined: CHINA, Guangdong Province, Huazhou, isolated from a healthy twig of C. grandis "Tomentosa," May 2019, ZY Dong and YX Shu, (dried culture ZHKU 20-0001); living culture ZHKUCC 20-0001).

Habitat and host: Betula spp. (Du et al., 2016); Brassica oleracea var. acephala (Turkkan et al., 2020); Camellia sinensis (Gao et al., 2016), Camptotheca acuminate (Yang et al., 2017b); Juglans regia (Fan et al., 2018); peach (Dissanayake et al., 2017a); Sambucus williamsii (Caprifoliaceae) (Yang et al., 2018a); Schisandra chinensis (Schisandraceae) (Yang et al., 2018a); Senna bicapsularis (Yang et al., 2017a).

Known distribution: China; Turkey (Farr and Rossman, 2020).

Note: A single isolate in the present study clustered together with the Diaporthe apiculata ex-type strain (CGMCC 3.17533) with 71\% maximum likelihood bootstrap value and 0.89 Bayesian posterior probabilities. Colony morphology and conidial dimensions of the present isolate (ZHKUCC 20-0001) were similar to those in the original description of D. apiculata (Gao et al., 2016). Diaporthe apiculata was introduced by Gao et al. (2016) for a species associated with healthy leaves of Camellia. This is the first report of D. apiculata on C. grandis cv. "Tomentosa" (Farr and Rossman, 2020).

\section{Diaporthe aquatica}

D.M. Hu, L. Cai and K.D. Hyde, Mycologia 104(6): 1481 (2012) Index Fungorum number: IF564857, Faces of fungi Number: FoF08404 (Figure 3).

Endophytic on C. grandis "Tomentosa" fruits. Sexual morph: not observed. Asexual morph: Pycnidia 150$510 \mu \mathrm{m} \times 100-500 \mu \mathrm{m}(\bar{x}=294 \pm 102 \mu \mathrm{m} \times 239 \pm 98 \mu \mathrm{m})$, globose to subglobose, black, coriaceous, immersed to semiimmersed, single to clustered, conidia produced in yellow to brown creamy drops. Conidiophores 10-60 $\mu \mathrm{m} \times 2-3 \mu \mathrm{m}$ $(\bar{x}=22 \pm 9 \mu \mathrm{m} \times 2 \pm 0.4 \mu \mathrm{m})$, cylindrical, hyaline. Alpha conidia 6-8 $\mu \mathrm{m} \times 2-3 \mu \mathrm{m}(\bar{x}=7 \pm 0.6 \mu \mathrm{m} \times 3 \pm 0.4 \mu \mathrm{m})$, ellipsoidal to fusiform, hyaline, slightly constricted in the middle, some with one end rounded and the others acute, with two to five guttules. Beta conidia 6-43 $\mu \mathrm{m} \times 1-2 \mu \mathrm{m}(\bar{x}=25 \pm 9 \mu \mathrm{m} \times 1 \pm 0.3 \mu \mathrm{m})$, filiform, hyaline, aseptate, and curved at one end.

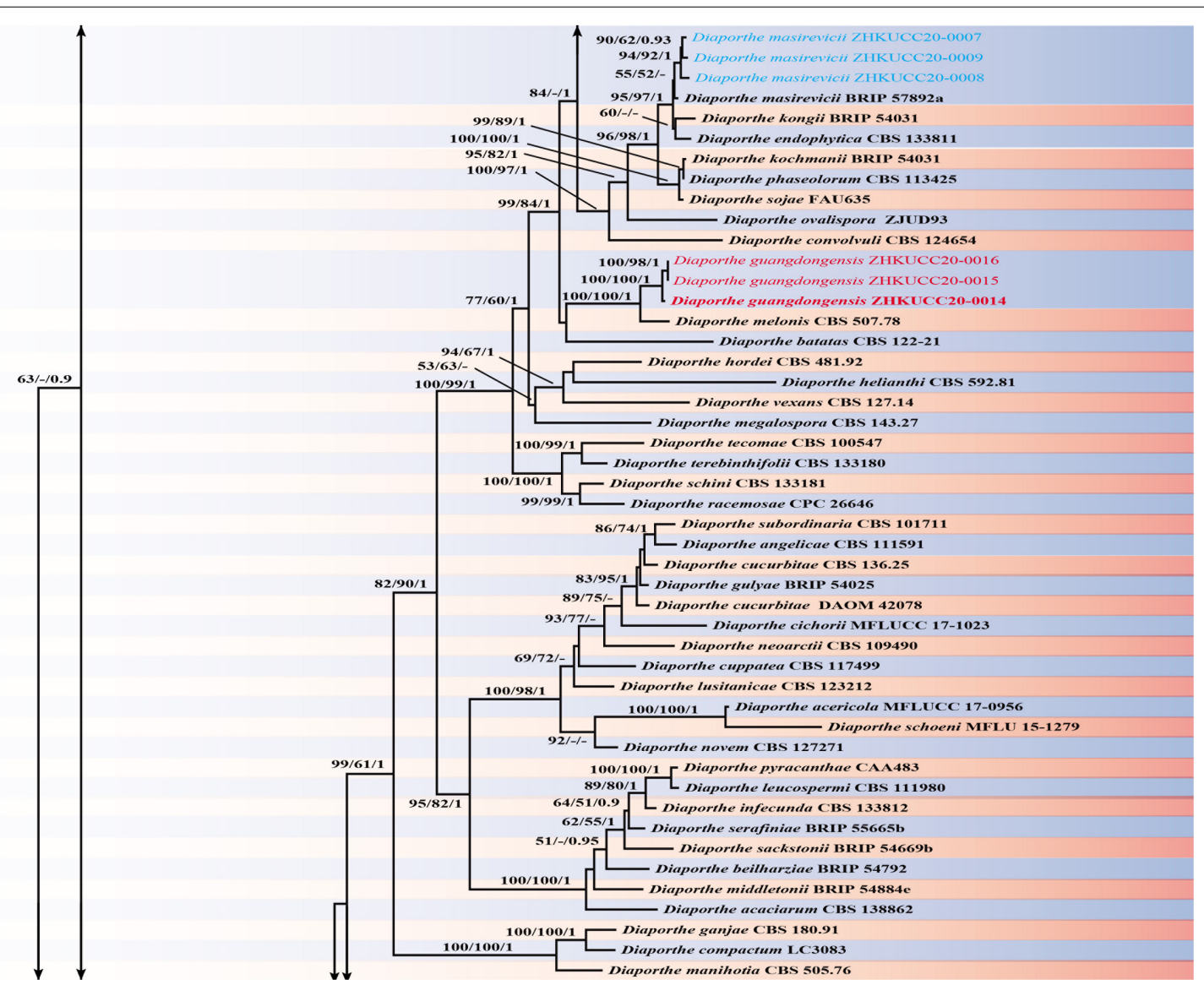

FIGURE 1 | Continued 


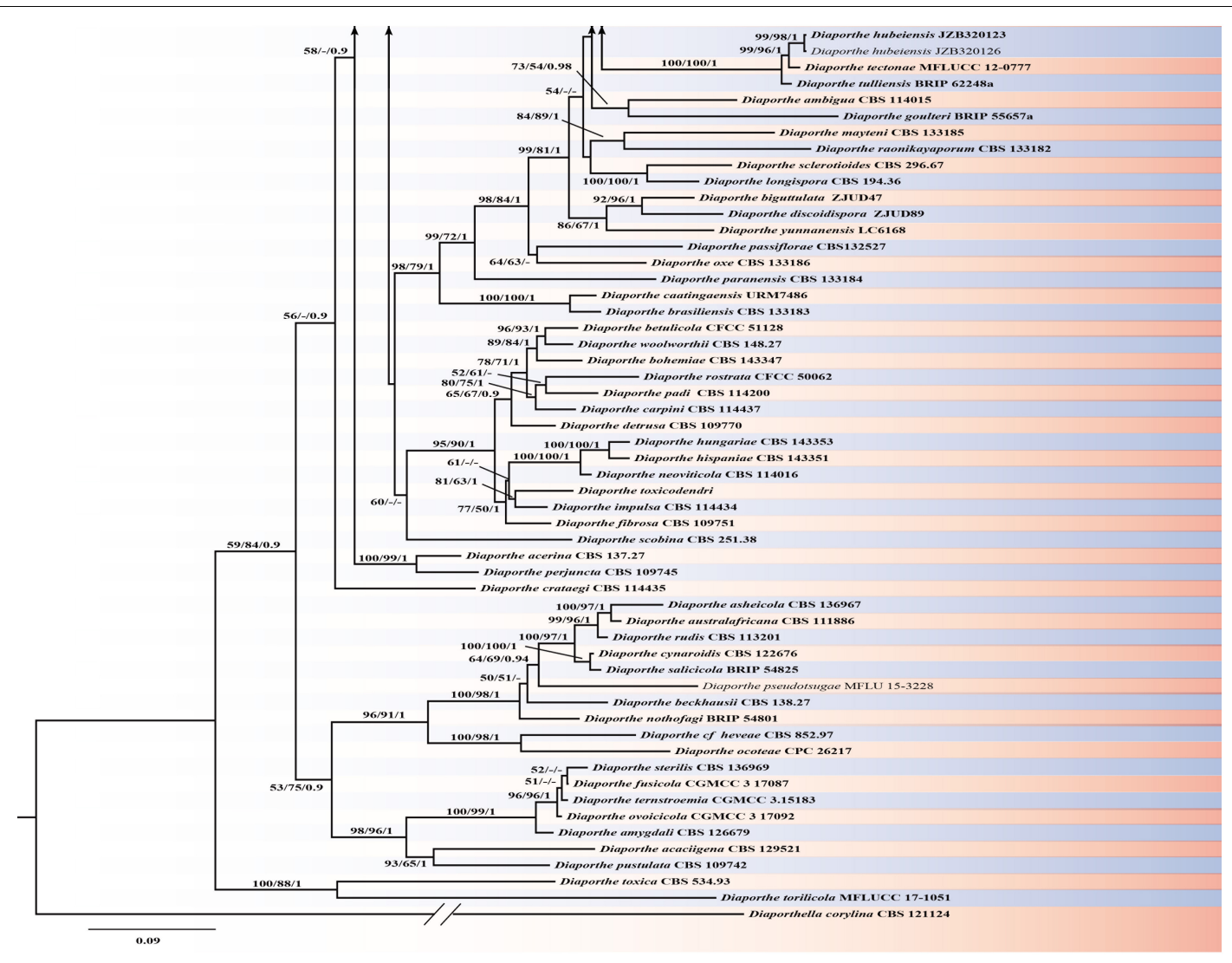

FIGURE 1 | The best scoring RAxML tree obtained using the combined dataset of ITS, tef1, tub2, and cal sequences. Diaporthella corylina (CBS 121124) was used to root the tree. Bootstrap support values equal to or greater than 50\% in ML and MP and BYPP equal or greater than 0.95 are shown as ML/MP/BYPP above the respective node. The isolates belonging to the current study are given in blue for known species, and novel taxa are shown in red. Ex-type strains are bold. Expected number of nucleotide substitutions per site is represented by the scale bar.

Culture Characteristics: Colonies on PDA reach $85 \mathrm{~mm}$ diam. after 5 days at $25^{\circ} \mathrm{C}$. Aerial mycelium, white, undulate margin, forming concentric rings of pycnidia. Reverse white, and then turning to brown-yellow from the center.

Material examined: CHINA, Guangdong Province, Huazhou, isolated from healthy fruits of C. grandis “Tomentosa," May 2019, ZY Dong and YX Shu, (dried culture ZHKU 20-0002); living culture ZHKUCC 20-0002).

Habitat and host: Freshwater fungus (Hu et al., 2012).

Known distribution: China (Hu et al., 2012).

Note: Isolate ZHKUCC 20-0002 obtained in this study clusters together with the ex-type isolate of Diaporthe aquatica (IFRDCC3051) with 66\% maximum likelihood bootstrap and 0.95 Bayesian posterior probability values. Alpha and beta conidia of this strain have a similar length to Diaporthe aquatica ( $\mathrm{Hu}$ et al., 2012). So far, this species has been reported only as a freshwater fungus from China (Hu et al., 2012). This is the first report of D. aquatica on C. grandis cv. "Tomentosa" (Farr and Rossman, 2020).

\section{Diaporthe arecae}

(H.C. Srivast., Zakia and Govindar) R.R. Gomes, C. Glienke and Crous, Persoonia 31: 16 (2013).
Index Fungorum number: 802924, Faces of fungi: FoF 08405 (Figure 4).

Endophytic on C. grandis "Tomentosa" twigs. Sexual morph: not observed. Asexual morph: Pycnidia 95$730 \mu \mathrm{m} \times 87-640 \mu \mathrm{m}(\bar{x}=419 \pm 167 \mu \mathrm{m} \times 361 \pm 164 \mu \mathrm{m})$, subglobose or lageniform. Conidiophores 7-38 $\mu \mathrm{m} \times 1-3 \mu \mathrm{m}$ $(\bar{x}=22 \pm 8 \mu \mathrm{m} \times 2 \pm 0.4 \mu \mathrm{m})$, cylindrical, hyaline. Alpha conidia 6-10 $\mu \mathrm{m} \times 2-3 \mu \mathrm{m}(\bar{x}=8 \pm 0.8 \mu \mathrm{m} \times 2 \pm 0.4 \mu \mathrm{m})$, cylindrical to ellipsoid, hyaline, aseptate, both ends acute, mostly biguttulate. Beta conidia 17-26 $\mu \mathrm{m} \times 1-2 \mu \mathrm{m}(\bar{x}=22 \pm 2 \mu \mathrm{m} \times 2 \pm 0.2 \mu \mathrm{m})$, filiform, hyaline, aseptate, curved at one end, one end blunt and the other end pointed.

Culture Characteristics: After 5 days at $25^{\circ} \mathrm{C}$ colonies reach $85 \mathrm{~mm}$ diam. on PDA. White radial, margin undulate. Reverse white, becoming tawny then dark brown from the center.

Material examined: CHINA, Guangdong Province, Huazhou, isolated from a healthy twig of C. grandis “Tomentosa," May 2019, ZY Dong and YX Shu, (dried cultures ZHKU 20-0003); living cultures ZHKUCC 20-0003).

Habitat and host: Areca catechu (Gomes et al., 2013), Citrus grandis, Citrus limon, Citrus reticulata, Citrus unshiu (Huang et al., 2015), Citrus sinensis (Huang et al., 2015; 

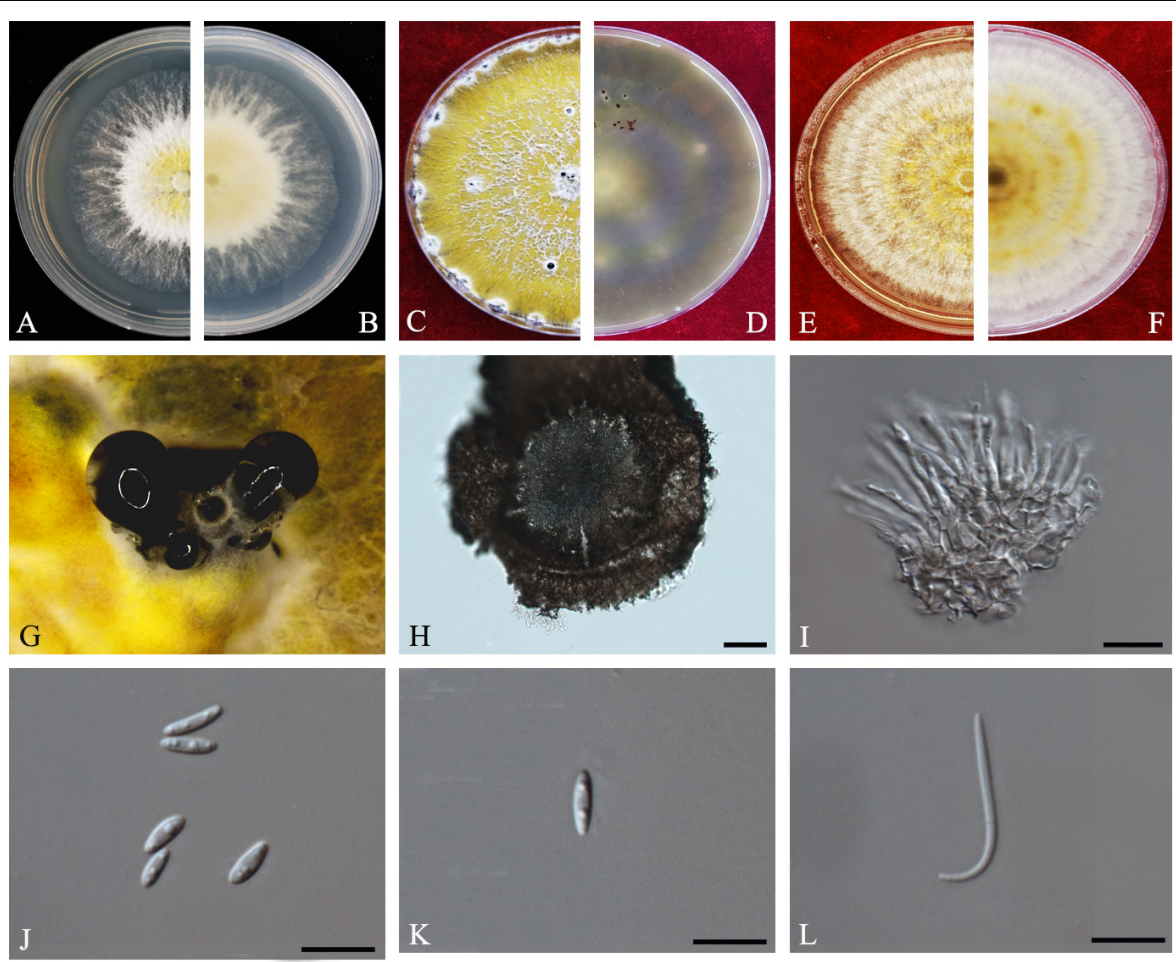

FIGURE 2 | Diaporthe apiculata (ZHKUCC 20-0001). (A,B) Colonies on PDA after 4 days at $25^{\circ} \mathrm{C}$, (C,D) Colonies on PDA after 30 days at $25^{\circ} \mathrm{C}$, (E,F) Colonies on MEA after 14 days at $25^{\circ} \mathrm{C}$, (G) Conidiomata sporulating on PNA, (H) Pycnidium, (I) Conidiogenous cells, (J,K) Alpha conidia, and (L) Beta conidia. Scale bars: (H) $=100 \mu \mathrm{m} ;(\mathbf{I}-\mathbf{L})=10 \mu \mathrm{m}$

Guarnaccia and Crous, 2017), Citrus sp. (Gomes et al., 2013; Guarnaccia and Crous, 2017). Mangifera indica (Lim et al., 2019).

Known distribution: India, China, Suriname, Malaysia (Farr and Rossman, 2020).

Note: The single isolate (ZHKUCC 20-0003) obtained in this study clustered with Diaporthe arecae (CBS 161.64) with $72 \%$ maximum likelihood, $76 \%$ maximum parsimony bootstrap values and 1.0 Bayesian posterior probability values. The isolate in this study was morphologically similar to the Diaporthe arecae type description (Gomes et al., 2013) by developing conidia with similar shapes and dimensions. This species was first reported on Citrus in China by Huang et al. (2015). Diaporthe arecae has been reported as being saprobic and pathogenic on Citrus and the pathogenicity of this species was confirmed by Guarnaccia and Crous (2017).

\section{Diaporthe biconispora}

F. Huang, K.D. Hyde and H.Y. Li, Fungal Biology 119(5): 338 (2015) Index Fungorum number: IF810578, Faces of fungi: FoF08406 (Figure 5).

Endophytic on C. grandis "Tomentosa" leaves. Sexual morph: not observed. Asexual morph: Pycnidia 150-770 $\mu \mathrm{m} \times 75-$ $430 \mu \mathrm{m}(\bar{x}=275 \mu \mathrm{m} \times 210 \mu \mathrm{m})$, globose to sub-globose, brown to dark brown, conidia produced in white to transparent creamy and yellow drops. Conidiophores 10-45 $\mu \mathrm{m} \times 1-$ $4 \mu \mathrm{m}(\bar{x}=22 \pm 9 \mu \mathrm{m} \times 2 \pm 0.6 \mu \mathrm{m})$, cylindrical to subcylindrical, simple, hyaline. Alpha conidia 4-7 $\mu \mathrm{m} \times 2-3 \mu \mathrm{m}$ $(\bar{x}=6 \pm 1 \mu \mathrm{m} \times 3 \pm 0.3 \mu \mathrm{m})$, cylindrical to ellipsoid, hyaline, aseptate, biguttulate or multiguttulate. Beta conidia 24$37 \mu \mathrm{m} \times 1-2 \mu \mathrm{m}(\bar{x}=30 \pm 4 \mu \mathrm{m} \times 2 \pm 0.2 \mu \mathrm{m})$, filiform, hyaline, aseptate and curved at one end.

Culture Characteristics: Cultures reach $75 \mathrm{~mm}$ diam. on $\mathrm{PDA}$ at $25^{\circ} \mathrm{C}$ after 5 days. White to light yellow, aerial mycelium, circular, entire margin. Reverse light yellow, black pigmentation at the center.

Material examined: CHINA, Guangdong Province, Huazhou, isolated from a healthy leave of C. grandis cv. "Tomentosa," May 2019, ZY Dong and YX Shu, (dried culture ZHKU 20-0004); living culture ZHKUCC 20-0004).

Habitat and host: Betula spp. (Du et al., 2016) Citrus grandis (Huang et al., 2015), Citrus maxima (Fan et al., 2018), Citrus sinensis (Huang et al., 2015), Fortunella margarita (Huang et al., 2015), Senna bicapsularis (Yang et al., 2017a).

Known distribution: China (Farr and Rossman, 2020).

Note: One isolate in this study clustered with Diaporthe biconispora (ZJUD62) with $100 \%$ maximum likelihood, $100 \%$ maximum parsimony bootstrap values and 1.0 Bayesian posterior probability values. Colony morphology and conidial characters of this isolate (ZHKUCC 200004) are similar to those in the type description of D. biconispora (Huang et al., 2015). The isolate (ZHKUCC 20-0004) obtained in this study developed beta conidia whereas type strain did not (Huang et al., 2015). Diaporthe biconispora was introduced by Huang et al. (2015) as an 

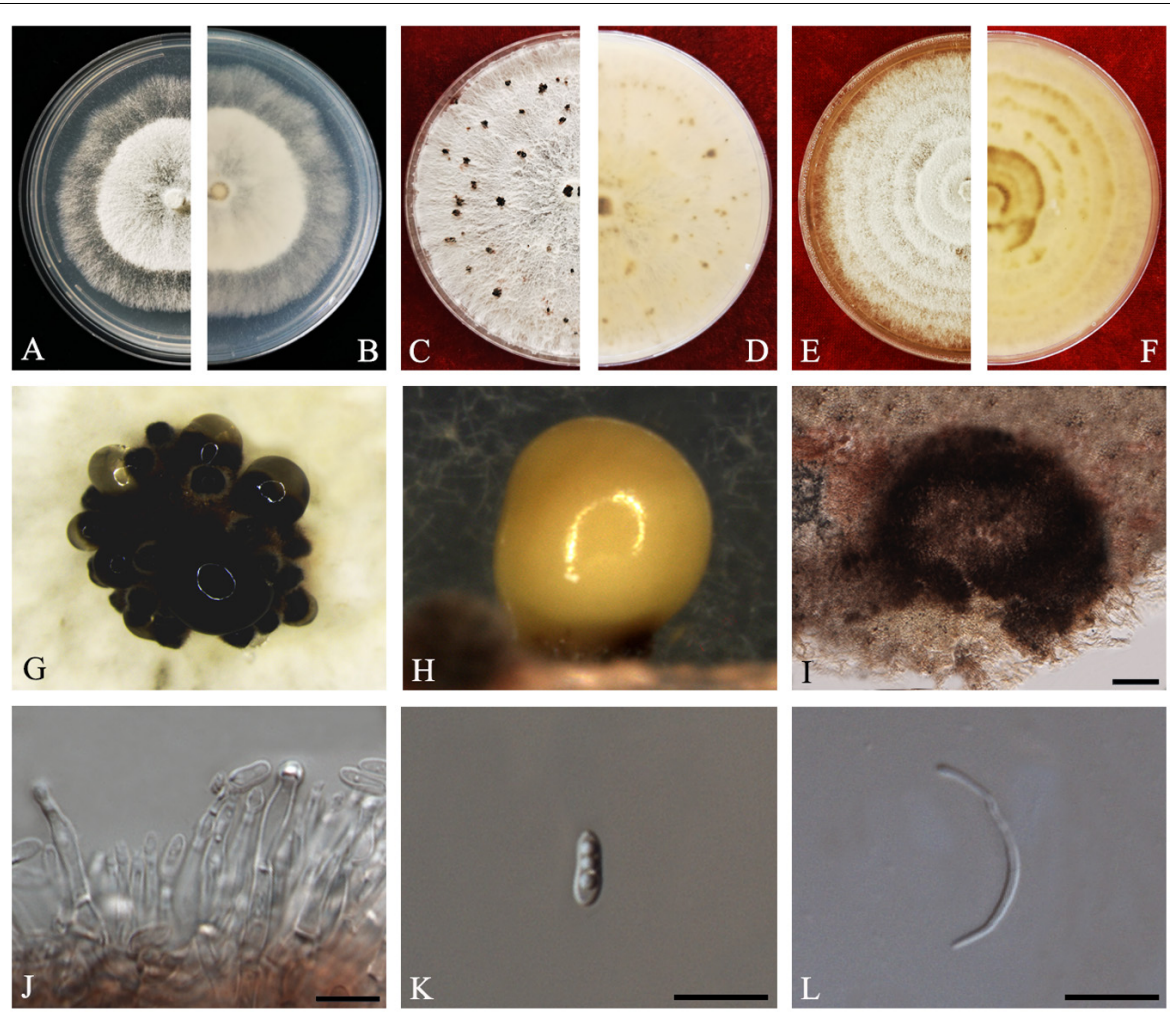

FIGURE 3 | Diaporthe aquatica (ZHKUCC 20-0002). (A,B) Colonies on PDA after 4 days at $25^{\circ} \mathrm{C},(\mathbf{C}, \mathbf{D})$ Colonies on PDA after 30 days at $25^{\circ} \mathrm{C}$, (E,F) Colonies on MEA after 14 days at $25^{\circ} \mathrm{C},(\mathbf{G}, \mathbf{H})$ Conidiomata sporulating on PDA, (I) Pycnidium, (J) Conidiogenous cells, (K) Alpha conidia, and (L) Beta conidia. Scale bars: (I) $=100 \mu \mathrm{m} ;(\mathbf{J}-\mathbf{L})=10 \mu \mathrm{m}$.

endophytic fungus from Citrus grandis, C. sinensis, and Fortunella margarita.

\section{Diaporthe endocitricola}

Z.Y. Dong, M. Luo, M.M. Xiang, K.D. Hyde, sp. nov. Index fungorum number: IF557628, Faces of fungi: FoF 08409 (Figure 6).

Etymology-In reference to its endophytic nature in Citrus grandis.

Holotype-ZHKUCC 20-0012.

Endophytic on C. grandis "Tomentosa” fruits. Sexual morph: not observed. Asexual morph: Pycnidia 124-790 $\mu \mathrm{m} \times 111-$ $635 \mu \mathrm{m}(\bar{x}=353 \pm 170 \mu \mathrm{m} \times 289 \pm 134 \mu \mathrm{m})$, multilocular, subglobose or lageniform, ostiolate, produced in hyaline to dark black creamy drops. Conidiophores 12-40 $\mu \mathrm{m} \times 1-3 \mu \mathrm{m}$ $(\bar{x}=26 \pm 7 \mu \mathrm{m} \times 2 \pm 0.3 \mu \mathrm{m})$, formed from the inner layer of the locular wall, cylindrical, hyaline. Alpha conidia 6-8 $\mu \mathrm{m} \times 2-3 \mu \mathrm{m}(\bar{x}=7 \pm 1 \mu \mathrm{m} \times 3 \pm 0.3 \mu \mathrm{m})$, cylindrical to ellipsoid, hyaline, aseptate, mostly multiguttulate with guttules focus on both ends. Beta conidia $12-30 \mu \mathrm{m} \times 1-$ $2 \mu \mathrm{m}(\bar{x}=19 \pm 4 \mu \mathrm{m} \times 2 \pm 0.2 \mu \mathrm{m})$, filiform, hyaline, aseptate, straight or curved at one end. Gamma conidia fusiform, hyaline, multiguttulate.

Culture characteristics: Cultures reach $85 \mathrm{~mm}$ diam., after 5 days on $\mathrm{PDA}$ at $25^{\circ} \mathrm{C}$. White with radial hyphal growth at the rim, circular form with entire margin, with some irregular conidiomata after 20 days. Reverse white becoming yellowbrown, with zonations.

Material examined: CHINA, Guangdong Province, Huazhou, isolated from healthy fruits of C. grandis cv. "Tomentosa," May 2019, ZY Dong and YX Shu, (dried culture ZHKU 20-0012 holotype and ZHKU 20-0013 paratype); living cultures ZHKUCC 20-0012 ex-type and ZHKUCC 20-0013 ex-paratype.

Habitat and host: On healthy fruits of C. grandis cv. "Tomentosa"

Known distribution: China (Huazhou, Guangdong provinces).

Note: In the multigene phylogenetic tree developed using ITS, tef1, tub2, and cal, two isolates (ZHKUCC 20-0012 and ZHKUCC 20-0013) from the present study developed a sister clade to D. millettiae (GUCC9167) with 100\% maximum likelihood, $100 \%$ maximum parsimony bootstrap and 1.0 Bayesian posterior probability values. Morphologically, Diaporthe endocitricola has more guttules in alpha conidia (mostly multiguttulate with guttules focused on both ends) than $D$. millettiae (mostly biguttulate) (Long et al., 2019). In addition to that, D. endocitricola has longer conidiophores (12-38 $\mu \mathrm{m} \times 1-3 \mu \mathrm{m})$ than D. millettiae (10-23 × 1-2.5) (Long et al., 2019). Diaporthe endocitricola develops gamma conidia while $D$. millettiae does not (Long et al., 2019). When of four gene regions compared between $D$. endocitricola and $D$. millettiae, $D$. millettiae has 1.6\% nucleotide differences in ITS along 549 nucleotides. In comparisons of protein-coding regions, $3 \%$ differences in tef 1 

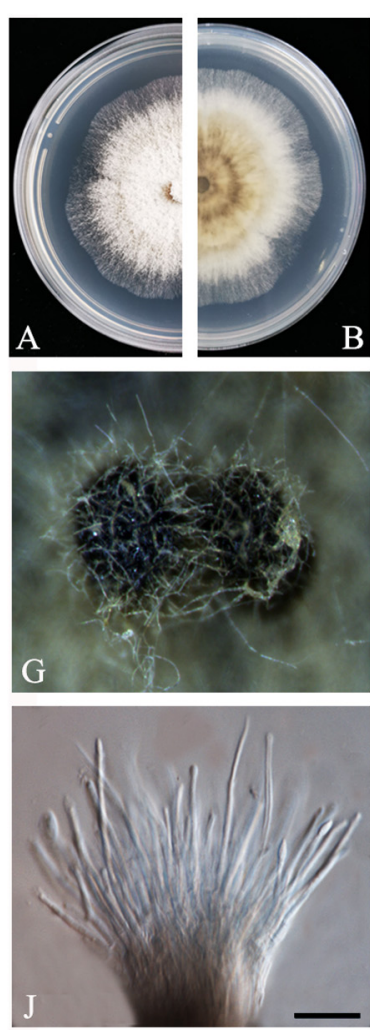

K
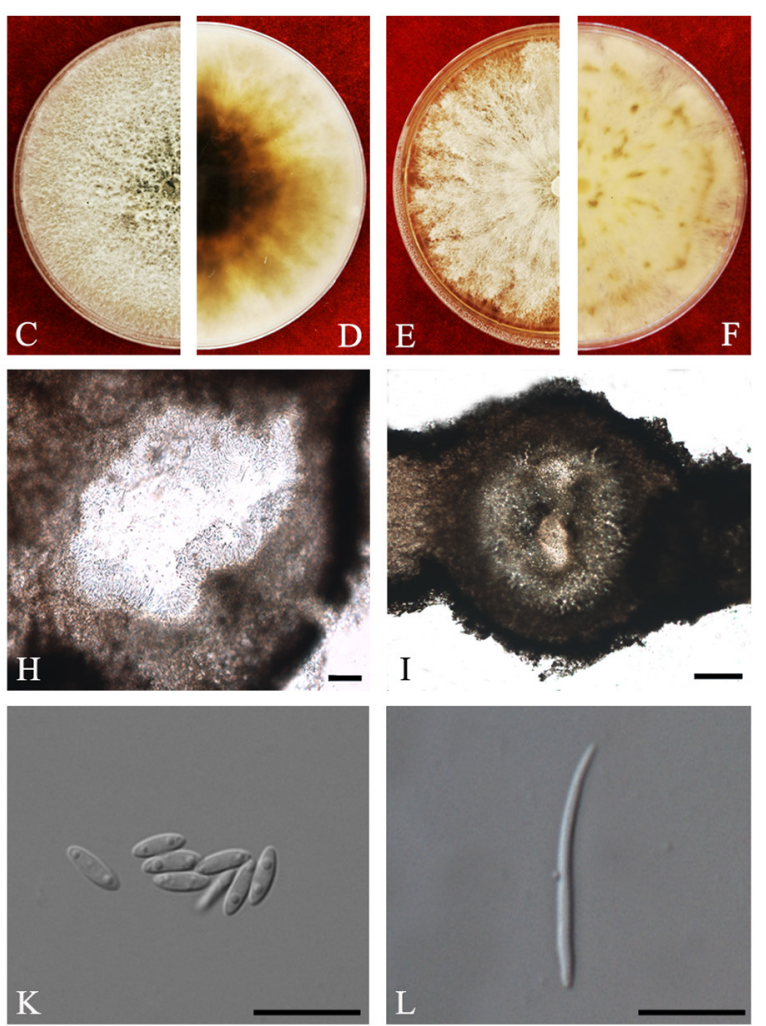

FIGURE 4 | Diaporthe arecae (ZHKUCC 20-0003). (A,B) Colonies on PDA after 4 days at $25^{\circ} \mathrm{C}$, (C,D) Colonies on PDA after 30 days at $25^{\circ} \mathrm{C}$, (E,F) Colonies on MEA after 14 days at $25^{\circ} \mathrm{C}$, (G) Conidiomata sporulating on PNA, (H,I) Pycnidium, (J) Conidiogenous cells, (K) Alpha conidia, and (L) Beta conidia. Scale bars: $\mathbf{( H , I )}=100 \mu \mathrm{m} ;(\mathbf{J}-\mathbf{L})=10 \mu \mathrm{m}$.
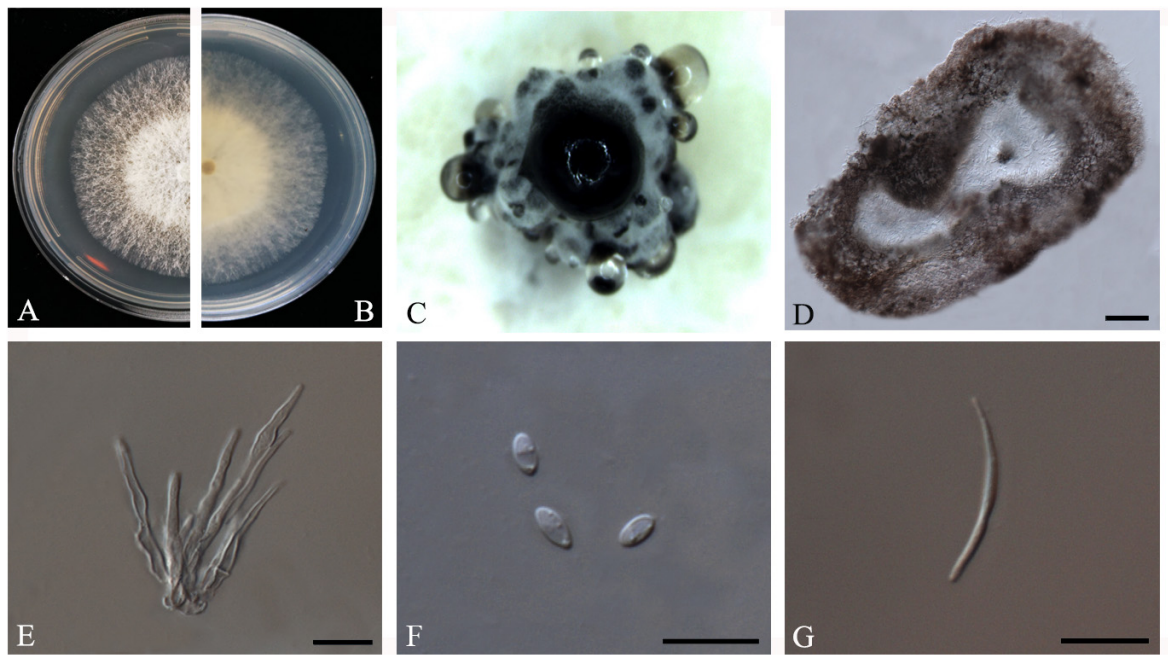

FIGURE 5 | Diaporthe biconispora (ZHKUCC 20-0004). (A,B) Colonies on PDA after 4 days at 25ㄷ, (C) Conidiomata sporulating on PDA, (D) Pycnidium, (E) Conidiogenous cells, (F) Alpha conidia, and (G) Beta conidia. Scale bars: (D) $=100 \mu \mathrm{m}$; (E-G) $=10 \mu \mathrm{m}$.

(332 nucleotides), 4\% differences in tub2 (513 nucleotides), $1 \%$ differences in cal (440 nucleotides). Considering both morphological and molecular data, these isolates were identified as a novel species.

\section{Diaporthe guangdongensis}

Z.Y. Dong, M. Luo, M.M. Xiang, K.D. Hyde, sp. nov. Index Fungorum number: IF557627, Faces of fungi: FoF08410 (Figure 7). 

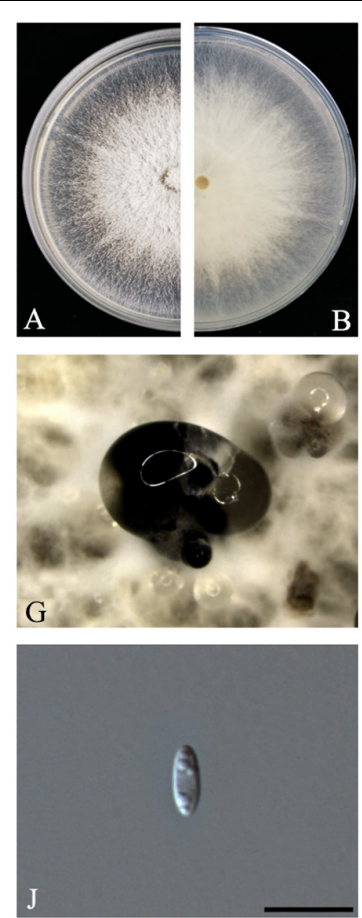
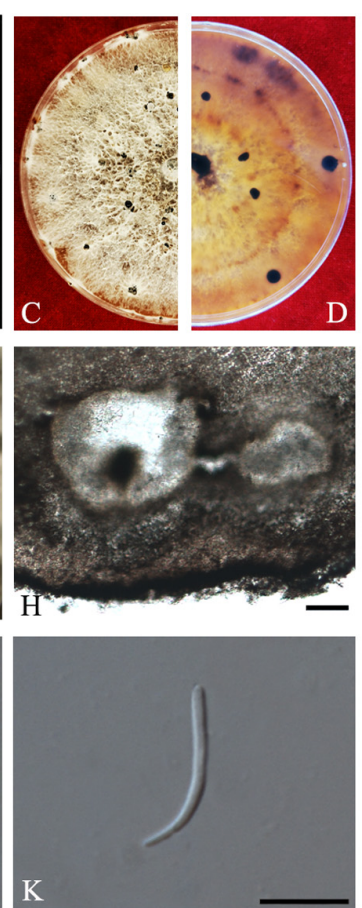
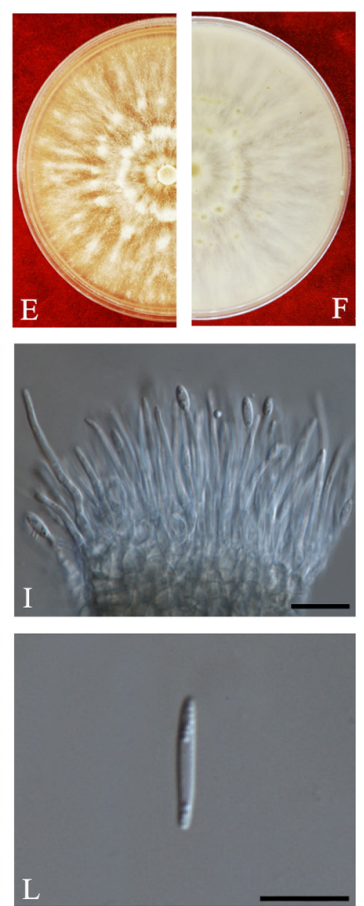

FIGURE 6 | Diaporthe endocitricola (ZHKUCC 20-0012, Holotype). (A,B) Colonies on PDA after 4 days at $25^{\circ} \mathrm{C}$, (C,D) Colonies on PDA after 30 days at $25^{\circ} \mathrm{C}$, (E,F) Colonies on MEA after 14 days $25^{\circ} \mathrm{C}$, (G) Conidiomata sporulating on PDA, (H) Pycnidium, (I) Conidiogenous cells, (J) Alpha conidia, (K) Beta conidia, and (L) Gamma conidia. Scale bars: (H) = $100 \mu \mathrm{m}$; (I-L) $=10 \mu \mathrm{m}$
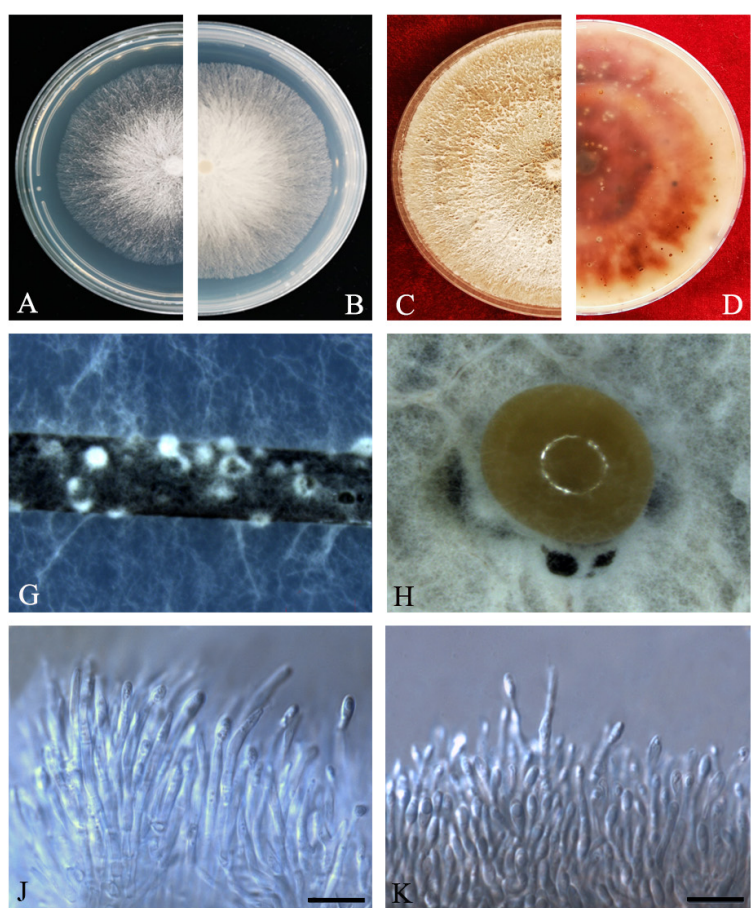
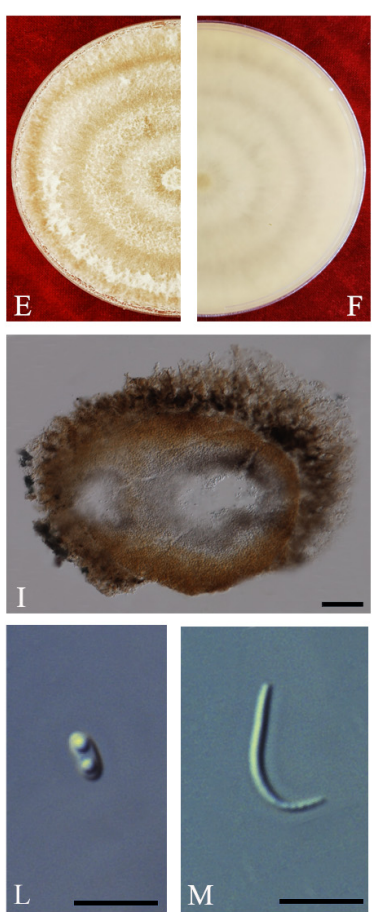

FIGURE 7 | Diaporthe guangdongensis (ZHKUCC 20-0014 Holotype). (A,B) Colonies on PDA after 2 days at $25^{\circ} \mathrm{C},(\mathbf{C}, \mathbf{D}) \mathrm{Colonies}$ on PDA after 30 days at $25^{\circ} \mathrm{C}$, (E,F) Colonies on MEA after 14 days at $25^{\circ} \mathrm{C}$, (G) Conidiomata sporulating on PNA, (H) Conidiomata sporulating on PDA, (I) Pycnidium, (J,K) Conidiogenous cells, (L) Alpha conidia, and (M) Beta conidia. Scale bars: $\mathbf{( H )}=100 \mu \mathrm{m}$; (I-M) = $10 \mu \mathrm{m}$. 
Etymology-In reference to the Guangdong province, from where the samples were collected.

Holotype-ZHKUCC 20-0014.

Endophytic on C. grandis "Tomentosa" fruits. Sexual morph: not observed. Asexual morph: Pycnidia 130-515 $\mu \mathrm{m} \times 100-$ $390 \mu \mathrm{m}(\bar{x}=286 \pm 101.4 \mu \mathrm{m} \times 229 \pm 76 \mu \mathrm{m})$, subglobose or lageniform, solitary, with neck, conidia produced in yellowishbrown to blackish green creamy drops. Conidiophores 11$46 \mu \mathrm{m} \times 1-3 \mu \mathrm{m}(\bar{x}=24 \pm 9 \mu \mathrm{m} \times 2 \pm 0.4 \mu \mathrm{m})$, branched, densely aggregated, cylindrical, straight to sinuous, hyaline, 1-3-septate. Alpha conidia 6-8 $\mu \mathrm{m} \times 2-4 \mu \mathrm{m}$ $(\bar{x}=7 \pm 0.5 \mu \mathrm{m} \times 3 \pm 0.4 \mu \mathrm{m})$, hyaline, unicellular, fusiform to ellipsoidal, with two big guttules. Beta conidia $14-35 \mu \mathrm{m} \times 1-$ $2 \mu \mathrm{m}(\bar{x}=21 \pm 4 \mu \mathrm{m} \times 2 \pm 0.2 \mu \mathrm{m})$, filiform, hyaline, unicellular, aseptate and curved at one end.

Culture Characteristics: Cultures reach $85 \mathrm{~mm}$ diam. after 3 days on PDA at $25^{\circ} \mathrm{C}$. White turn to yellowish-white with time, circular, entire margin. Reverse white and turn to reddish-brown from the center with time.

Material examined: CHINA, Guangdong Province, Huazhou, isolated from healthy fruits of C. grandis cv. "Tomentosa, May 2019, ZY Dong and YX Shu, (dried cultures ZHKU 20-0014, holotype and ZHKU 20-0015-16, isotype); living cultures ZHKUCC 20-0014 ex-type and ZHKUCC 20-001516 ex-isotype.

Habitat and host: On healthy fruit of C. grandis cv. "Tomentosa"

Known distribution: China (Huazhou, Guangdong provinces).

Note: In the phylogenetic tree developed using ITS, tefl, $t u b 2$, and cal, three isolates obtained in this study developed a sister clade to D. melonis (CBS 507.78) with $100 \%$ maximum likelihood, $100 \%$ maximum parsimony bootstrap, and 1.0 Bayesian posterior probability values. Morphologically, Diaporthe guangdongensis has shorter alpha conidia (6$8 \mu \mathrm{m} \times 2-4 \mu \mathrm{m}, \bar{x}=6.5 \pm 0.5 \mu \mathrm{m} \times 2.9 \pm 0.4 \mu \mathrm{m})$ than D. melonis $(6.3-10.3 \mu \mathrm{m} \times 2.16-3 \mu \mathrm{m}, \bar{x}=8.3 \times 2.6)$ (Beraha and O'Brien, 1979). Diaporthe guangdongensis has shorter beta conidia $(14-35 \times 1-2, \bar{x}=21 \pm 4 \mu \mathrm{m} \times 2 \pm 0.2 \mu \mathrm{m})$ than D. melonis $(8.6-27.7 \mu \mathrm{m} \times 1-2 \mu \mathrm{m}, \bar{x}=24.7 \times 1.3 \mu \mathrm{m})$. In comparisons of four gene regions between $D$. guangdongensis and D. melonis, $1.6 \%$ nucleotide difference was observed in ITS along 565 nucleotides. In comparisons of proteincoding regions, $3 \%$ differences in tef1 (352 nucleotides), $1.3 \%$ differences in tub2 (447 nucleotides), 2.8\% differences in cal (527 nucleotides) were observed. On the basis of these dissimilarities, the three isolates obtained in this study were described as a novel endophytic species associated with C. grandis "Tomentosa."

\section{Diaporthe limonicola}

Guarnaccia and Crous, IMA Fungus 8(2): 317-334 (2017) Index Fungorum number: IF821731, Faces of fungi: FoF08407 (Figure 8).

Endophytic on C. grandis "Tomentosa" leaves. Sexual morph: not observed. Asexual morph: Pycnidia 120$760 \mu \mathrm{m} \times 80-660 \mu \mathrm{m}(\bar{x}=400 \mu \mathrm{m} \times 330 \mu \mathrm{m})$, subglobose or lageniform, whitish cream to dark brown conidial drops exuded from the ostioles. Conidiophores 12-30 $\mu \mathrm{m} \times 1-$ $2 \mu \mathrm{m}(\bar{x}=20 \pm 7 \mu \mathrm{m} \times 2 \pm 0.3 \mu \mathrm{m})$, cylindrical, hyaline, smooth, densely aggregated. Alpha conidia 5-10 $\mu \mathrm{m} \times 2-$ $3 \mu \mathrm{m}(\bar{x}=7 \pm 1 \mu \mathrm{m} \times 2 \pm 0.4 \mu \mathrm{m})$, cylindrical to ellipsoid, hyaline, aseptate, mono- to biguttulate and acute at both ends. Beta conidia 14-29 $\mu \mathrm{m} \times 1-2 \mu \mathrm{m}$ $(\bar{x}=22 \pm 4 \mu \mathrm{m} \times 2 \pm 0.3 \mu \mathrm{m})$, filiform, hyaline, aseptate, straight or curved, tapering toward both ends. Gamma conidia cylindrical, hyaline, multiguttulate.

Culture Characteristics: At $25^{\circ} \mathrm{C}$ colonies reach $85 \mathrm{~mm}$ diam. on PDA after 5 days of inoculation. White, circular, entire margin, becoming cream to smoke-gray. Reverse white turning brown and dark gray, dark brown scattered pigmentation. Colonies on MEA at first white, then cream and become yellowish, flat, and dense. Reverse pale brown with conidiomata appearing as brownish dots that become black solitary or aggregated conidiomata at maturity.

Material examined: CHINA, Guangdong Province, Huazhou, isolated from a healthy fruit of C. grandis cv. "Tomentosa," May 2019, ZY Dong and YX Shu, (dried cultures ZHKU 20-0005-6); living cultures ZHKUCC 20-0005-6.

Habitat and host: Citrus limon (Guarnaccia and Crous, 2017).

Known distribution: Malta (Guarnaccia and Crous, 2017) and China (this study).

Note: Two isolates obtained in this study clustered together with Diaporthe limonicola (CBS H-23126) with 68\% maximum likelihood, 52\% maximum parsimony bootstrap, and 1.0 Bayesian posterior probability values. Morphologically both strains produced similarly shaped and similar sized conidia to the original description of D. limonicola (Guarnaccia and Crous, 2017). Diaporthe limonicola was introduced by Guarnaccia and Crous (2017) as a species associated with serious trunk and branch cankers of C. limon. This is the first report of D. limonicola on C. grandis cv. “Tomentosa” (Farr and Rossman, 2020).

\section{Diaporthe masirevicii}

R.G. Shivas, L. Morin, S.M. Thompson and Y.P. Tan, Persoonia 35: 45 (2015) Index Fungorum number: IF808671, Faces of fungi: FoF 08408 (Figure 9).

Endophytic on C. grandis "Tomentosa" twigs. Sexual morph: not observed. Asexual morph: Pycnidia 156$568 \mu \mathrm{m} \times 120-316 \mu \mathrm{m}(\bar{x}=256 \pm 88 \mu \mathrm{m} \times 201 \pm 51 \mu \mathrm{m})$, small, solitary, subglobose, conidia produced in subhyaline to brownish green drops. Conidiophores 9-36 $\mu \mathrm{m} \times 1-$ $4 \mu \mathrm{m}(\bar{x}=19 \pm 6 \mu \mathrm{m} \times 2 \pm 0.6 \mu \mathrm{m})$, subcylindrical or filiform, unbranched. Alpha conidia 6-10 $\mu \mathrm{m} \times 2-4 \mu \mathrm{m}$ $(\bar{x}=8 \pm 1 \mu \mathrm{m} \times 3 \pm 0.3 \mu \mathrm{m})$, cylindrical to ellipsoid, some with one end rounded and the others acute, hyaline, aseptate, biguttulate. Beta conidia 15-26 $\mu \mathrm{m} \times 1-2 \mu \mathrm{m}$ $(\bar{x}=21 \pm 3 \mu \mathrm{m} \times 2 \pm 0.3 \mu \mathrm{m})$, filiform, hyaline, tapering toward both ends, hamate or curved. Gamma conidia hyaline, multiguttulate. Beta conidia are much more than the alpha conidia in the PDA.

Culture Characteristics: Colonies in PDA reach $85 \mathrm{~mm}$ diam. after 5 days on at $25^{\circ} \mathrm{C}$. White aerial mycelium, irregular, undulate margin, develop concentric rings of pycnidia. Reverse white, and later become dark gray from the center. 

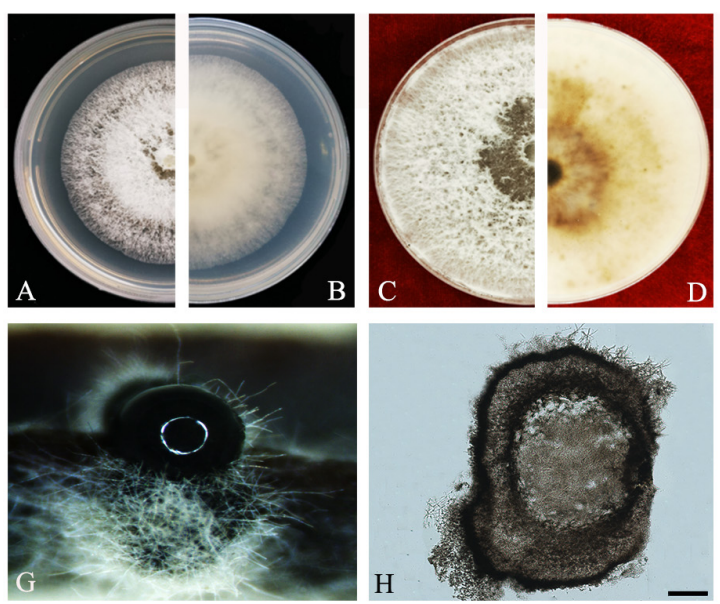

D
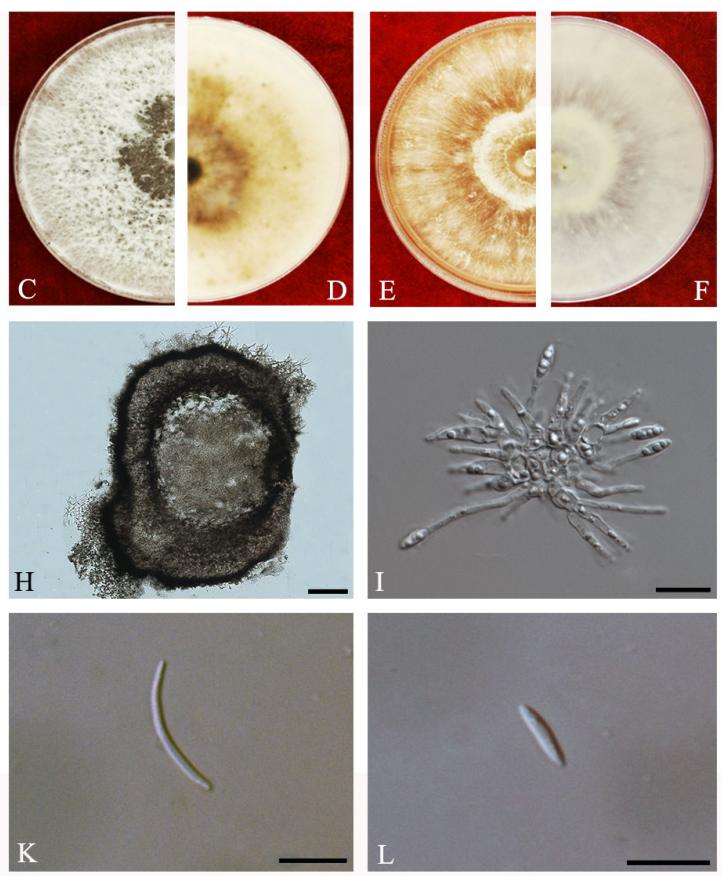

FIGURE 8 | Diaporthe limonicola (ZHKUCC 20-0005). (A,B) Colonies on PDA after 4 days at $25^{\circ} \mathrm{C},(\mathbf{C}, \mathbf{D})$. Colonies on PDA after 30 days at $25^{\circ} \mathrm{C}$, (E,F) Colonies on MEA after 14 days at $25^{\circ} \mathrm{C}$, (G) Conidiomata sporulating on PNA, (H) Pycnidium, (I) Conidiogenous cells, (J) Alpha conidia, (K) Beta conidia, and (L) Gamma conidia. Scale bars: $\mathbf{( H )}=100 \mu \mathrm{m} ; \mathbf{( I - L )}=10 \mu \mathrm{m}$.
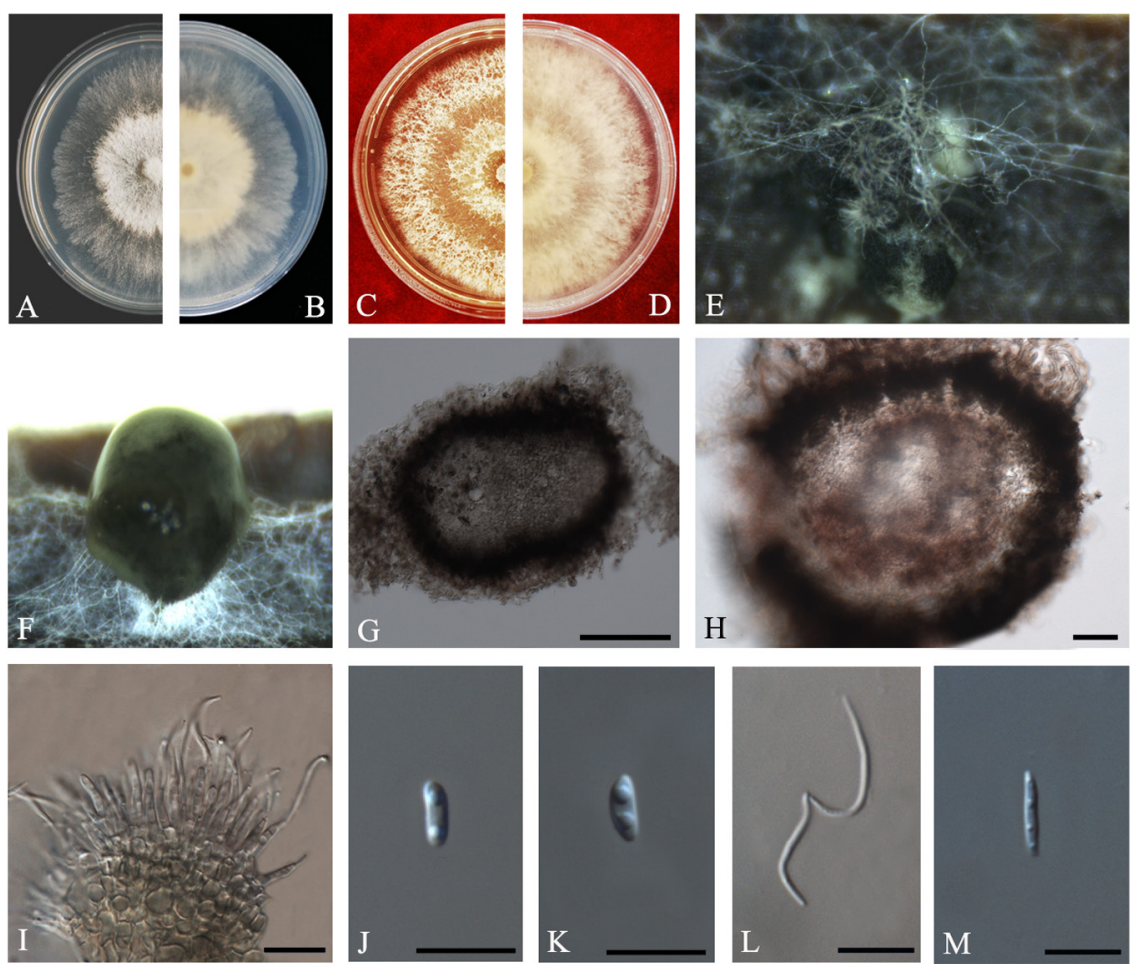

FIGURE 9 | Diaporthe masirevicii (ZHKUCC 20-0009). (A.B) Colonies on PDA after 4 days at $25^{\circ} \mathrm{C}$, (C,D) Colonies on MEA after 30 days at $25^{\circ} \mathrm{C}$, (E,F) Colonies on MEA after 14 days at $25^{\circ} \mathrm{C}$, (G) Conidiomata sporulating on PNA, (H) Pycnidium, (I) Conidiogenous cells, (J,K) Alpha conidia, (L) Beta conidia, and (M) Gamma conidia. Scale bars: $\mathbf{( G , H )}=100 \mu \mathrm{m} ;(\mathbf{I}-\mathbf{M})=10 \mu \mathrm{m}$. 
Material examined: CHINA, Guangdong Province, Huazhou, isolated from healthy fruits and healthy twigs of $C$. grandis $\mathrm{cv}$. “Tomentosa," May 2019, ZY Dong and YX Shu, (dried culture ZHKU 20-0007-9); living culture ZHKUCC 20-0007-9).

Habitat and host: Arachis hypogaea, Camellia sinensis, Chrysanthemoides monilifera, Chrysanthemoides monilifera subsp. rotundata, Gloriosa superba, Glycine max, Helianthus annuus, Physalis peruviana, and Zea mays (Farr and Rossman, 2020).

Known distribution: Australia (Thompson et al., 2015; Dissanayake et al., 2017b; Yang et al., 2018b), Brazil (Pazdiora et al., 2018), China (Gao et al., 2017; Yang et al., 2020), India (Naveen et al., 2018).

Note: Three isolates obtained in the present study clustered together with Diaporthe masirevicii (BRIP 57892a) with 94\% maximum likelihood, 92\% maximum parsimony bootstrap, and 1.0 Bayesian posterior probability values. Morphologically these strains produce beta and gamma conidia with similar lengths of those of the Diaporthe masirevicii type description (Thompson et al., 2015). Diaporthe masirevicii was introduced by Thompson et al. (2015) as a species associated with cankers or dead trees of Chrysanthemoides monilifera subsp. Rotundata, Glycine max, Helianthus annuus, and Zea mays. To our knowledge, this is the first report of D. masirevicii on C. grandis cv. "Tomentosa" (Farr and Rossman, 2020).

\section{Diaporthe passifloricola}

Crous \& M.J. Wingf., in Crous et al., Persoonia 36: 395 (2016) Index Fungorum number: IF817057, Faces of fungi: FoF 08411 (Figure 10).

Endophytic on C. grandis "Tomentosa" fruits and twigs. Sexual morph: not observed. Asexual morph: Pycnidia 107$388 \mu \mathrm{m} \times 90-256 \mu \mathrm{m}(\bar{x}=228 \pm 73 \mu \mathrm{m} \times 170 \pm 53 \mu \mathrm{m})$, pycnidial, black, globose, exuding gray to black creamy droplets. Conidiophores 9-35 $\mu \mathrm{m} \times 2-3 \mu \mathrm{m}$ $(\bar{x}=17 \pm 5 \mu \mathrm{m} \times 2 \pm 0.4 \mu \mathrm{m})$, hyaline, smooth, 2-3septate, branched, densely aggregated, cylindrical. Alpha conidia 6-7 $\mu \mathrm{m} \times 2-3 \mu \mathrm{m}(\bar{x}=7 \pm 0.3 \mu \mathrm{m} \times 3 \pm 0.2 \mu \mathrm{m})$, aseptate, hyaline, smooth, cylindrical, some with one end rounded and the others acute, with biguttulate. Beta conidia 18-26 $\mu \mathrm{m} \times 1-2 \mu \mathrm{m}$ $(\bar{x}=21 \pm 2 \mu \mathrm{m} \times 2 \pm 0.2 \mu \mathrm{m})$, smooth, hyaline, aseptate, spindle-shaped, apex acutely rounded, base truncate.

Culture Characteristics: Colonies on PDA reach $85 \mathrm{~mm}$ diam. on PDA at $25^{\circ} \mathrm{C}$ after 7 days. White, fluffy, aerial mycelium, and filiform margins. Reverse white, and later become yellow-brown to ochreous from the center.

Material examined: CHINA, Guangdong Province, Huazhou, isolated from healthy fruits and twigs of $C$. grandis $\mathrm{cv}$. “Tomentosa," May 2019, ZY Dong and YX Shu, (dried cultures ZHKU 20-0017-24); living cultures ZHKUCC 20-0017-24.

Habitat and host: Passiflora foetida (Crous et al., 2016).

Known distribution: China (this study) and Malaysia (Crous et al., 2016).

Note: In the combined multigene phylogenetic analysis of ITS, tef1, tub2, and cal, eight strains isolated in this study developed a well-supported clade with the D. passifloricola (CPC 27480) with $96 \% \mathrm{ML}, 96 \% \mathrm{MP}$ bootstrap and $1.0 \mathrm{BYPP}$ values.
In comparison between D. passifloricola and strains in the present study, they share morphologically similar characters as given in Crous et al. (2016). However, isolates obtained in this study have faster growth rate on PDA and radial margins. In addition, comparisons of gene regions between isolates from this study and $D$. passifloricola type, there is a $1.4 \%$ nucleotide difference in ITS with 555 nucleotides. In protein-coding regions, $0.55 \%$ differences in tub2 (547 nucleotides). This is the first record of D. passifloricola on C. grandis cv. "Tomentosa" (Farr and Rossman, 2020).

\section{Diaporthe perseae (Zerova)}

R.R. Gomes, Glienke and Crous, Persoonia 31: 29 (2013) Index Fungorum number: IF802944, Faces of fungi: FoF 08695 (Figure 11).

Endophytic on C. grandis "Tomentosa" leaves. Sexual morph: not observed. Asexual morph: Pycnidia 187-674 $\mu \mathrm{m} \times 141-$ $484 \mu \mathrm{m}(\bar{x}=394 \pm 142 \mu \mathrm{m} \times 280 \pm 94 \mu \mathrm{m})$, subglobose or lageniform, conidial drops yellowish, white and or transparent creamy. Conidiophores 10-28 $\mu \mathrm{m} \times 2-3 \mu \mathrm{m}$ $(\bar{x}=16 \pm 4 \mu \mathrm{m} \times 2 \pm 0.5 \mu \mathrm{m}), 1$-3-septate, hyaline, smooth, cylindrical to sinuous, branched, and densely aggregated straight. Alpha conidia 5-8 $\mu \mathrm{m} \times 2-3 \mu \mathrm{m}(\bar{x}=7 \pm 1 \mu \mathrm{m} \times 2 \pm 0.2 \mu \mathrm{m})$, aseptate, hyaline, smooth, fusoid to ellipsoid, tapering toward both ends, straight, apex subobtuse, base subtruncate, with two to four guttules. Beta conidia 17-28 $\mu \mathrm{m} \times 1-2 \mu \mathrm{m}$ $(\bar{x}=24 \pm 3 \mu \mathrm{m} \times 1 \pm 0.2 \mu \mathrm{m})$, aseptate, hyaline, spindle-shaped, smooth, apex acutely rounded, base truncate.

Culture Characteristics: Colonies on $\mathrm{PDA}$ at $25^{\circ} \mathrm{C}$ reach $85 \mathrm{~mm}$ diam. after 4 days. White and later turns pale white with patches of sienna, filamentous, entire margin. Reverse white, and with age produce umber color patches turning into sienna.

Material examined: CHINA, Guangdong Province, Huazhou, isolated from healthy leaves of C. grandis cv. "Tomentosa," May 2019, ZY Dong and YX Shu, (dried culture ZHKU 20-0010); living culture ZHKUCC 20-0010).

Habitat and host: Persea gratissima (Gomes et al., 2013), Mangifera indica (Lim et al., 2019).

Known distribution: Malaysia (Lim et al., 2019), Netherlands (Gomes et al., 2013) China (this study).

Note: A single isolate from the present study clustered together with the Diaporthe perseae (CBS 151.73) with 73\% maximum likelihood, $72 \%$ maximum parsimony bootstrap, and 1.0 bayesian posterior probability values. Morphologically this strain produces a similar length of both alpha and beta conidia to the Diaporthe perseae (Gomes et al., 2013). Diaporthe perseae was introduced by Gomes et al. (2013) as a species associated with branches of dying Persea gratissima. This is the first report of $D$. perseae on C. grandis (Farr and Rossman, 2020).

\section{Diaporthe sennae}

C.M. Tian and Qin Yang, in Yang, Fan, Du and Tian, Phytotaxa 302(2): 149 (2017) Index Fungorum number: IF820452, Faces of fungi: FoF08696 (Figure 12).

Endophytic on C. grandis "Tomentosa" leaves. Sexual morph: not observed. Asexual morph: Pycnidial, Pycnidia 149$756 \mu \mathrm{m} \times 95-692 \mu \mathrm{m}(\bar{x}=349 \pm 136 \mu \mathrm{m} \times 281 \pm 126 \mu \mathrm{m})$, 

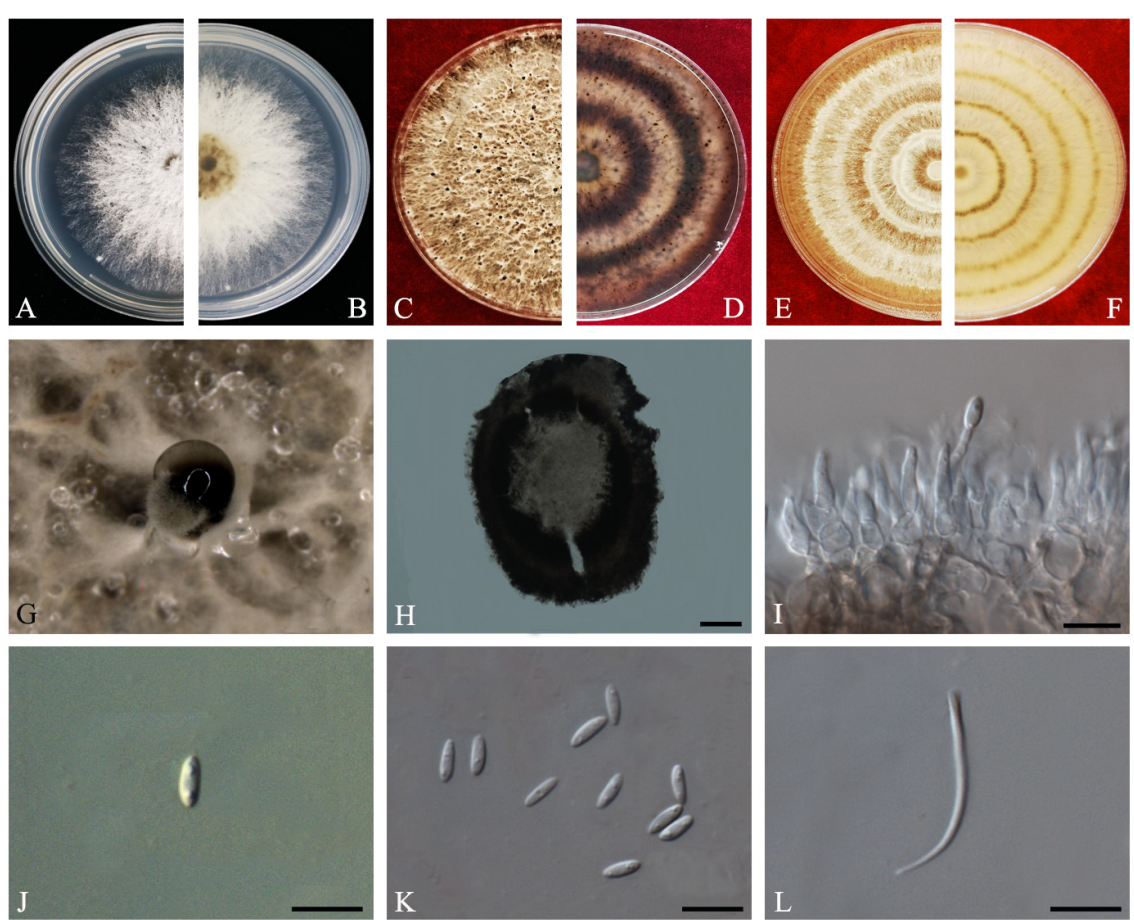

FIGURE 10 | Diaporthe passifloricola (ZHKUCC 20-0017). (A,B) Colonies on PDA after 4 days at $25^{\circ} \mathrm{C},(\mathbf{C}, \mathbf{D})$ Colonies on PDA after 30 days at $25^{\circ} \mathrm{C},(\mathbf{E}, \mathbf{F})$ Colonies on MEA after 14 days at $25^{\circ} \mathrm{C}$, (G) Conidiomata sporulating on PDA, (H) Pycnidium, (I) Conidiogenous cells, (J,K) Alpha conidia, and (L) Beta conidia. Scale bars: $(\mathbf{H})=100 \mu \mathrm{m} ;(\mathbf{I}-\mathbf{L})=10 \mu \mathrm{m}$.
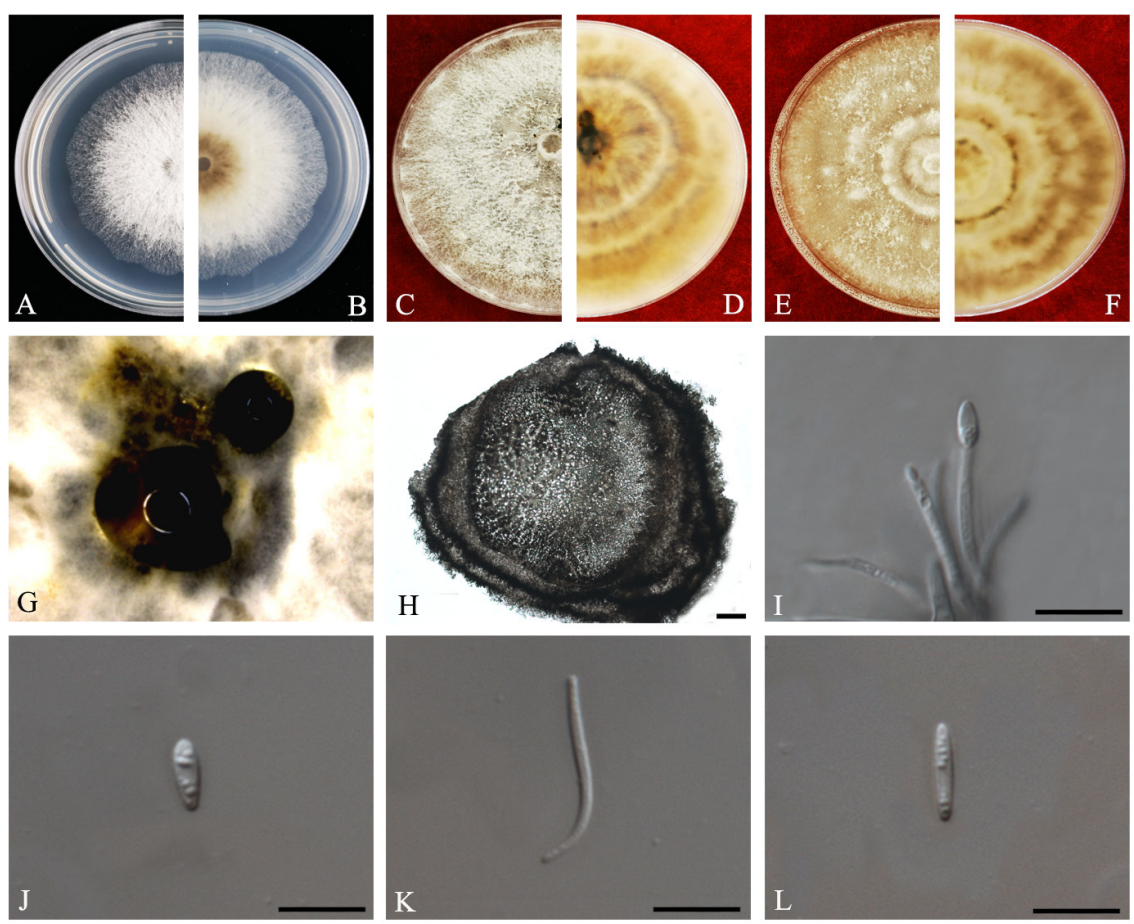

FIGURE 11 | Diaporthe perseae (ZHKUCC 20-0010). (A,B) Colonies on PDA after 3 days at $25^{\circ} \mathrm{C},(\mathbf{C}, \mathbf{D})$ Colonies on PDA after 30 days at $25^{\circ} \mathrm{C},(\mathbf{E}, \mathbf{F})$ Colonies on MEA after 14 days at $25^{\circ} \mathrm{C}$, (G) Conidiomata sporulating on PNA. (H) Pycnidium, (I) Conidiogenous cells, (J,K) Alpha conidia, and (L) Beta conidia. Scale bars: (H) $=100 \mu \mathrm{m} ;(\mathbf{I}-\mathbf{L})=10 \mu \mathrm{m}$. 

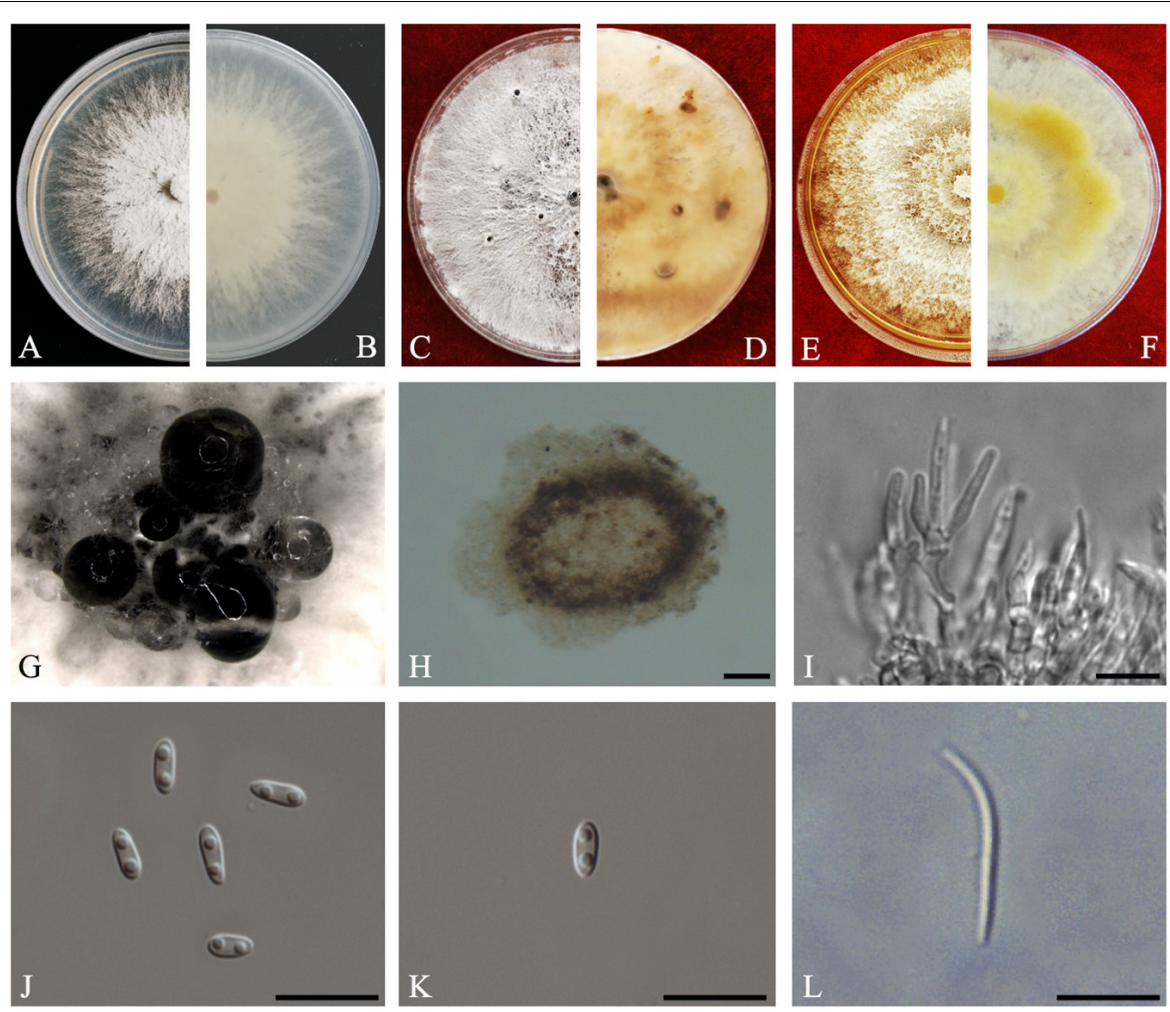

FIGURE 12 | Diaporthe sennae (ZHKUCC 20-0011). (A,B) Colonies on PDA after 4 days at 25ㄷ, (C,D) Colonies on PDA after 30 days at 25 C, (E,F) Colonies on MEA after 14 days at $25^{\circ} \mathrm{C}$, (G) Conidiomata sporulating on PDA, (H) Pycnidium, (I) Conidiogenous cells, (J) Alpha conidia, (K) Beta conidia, and (L) Gamma conidia. Scale bars: $\mathbf{( I )}=100 \mu \mathrm{m} ;(\mathbf{J}-\mathbf{L})=10 \mu \mathrm{m}$.

subglobose or lageniform, scattered, erumpent through the bark surface. Conidiophores 16-34 $\mu \mathrm{m} \times 1-3 \mu \mathrm{m}$ $(\bar{x}=23 \pm 5 \mu \mathrm{m} \times 2 \pm 0.4 \mu \mathrm{m})$, cylindrical, hyaline. Alpha conidia 6-8 $\mu \mathrm{m} \times 3-3 \mu \mathrm{m}(\bar{x}=7 \pm 1 \mu \mathrm{m} \times 3 \pm 0.2 \mu \mathrm{m})$, cylindrical to ellipsoid, hyaline, aseptate, smooth, multiguttulate, usually two guttules at each end. Gamma conidia cylindrical, hyaline, multiguttulate. Beta conidia $18-36 \mu \mathrm{m} \times 1-$ $2 \mu \mathrm{m}(\bar{x}=26 \pm 4 \mu \mathrm{m} \times 2 \pm 0.2 \mu \mathrm{m})$, hyaline, aseptate, straight to hamate.

Culture Characteristics: After 5 days on PDA, colonies reach $85 \mathrm{~mm}$ diam. at $25^{\circ} \mathrm{C}$. White, radial hyphal growth, becoming gray-white, develop pycnidia after 7 days. Reverse white, then pale brown from the center and forming concentric rings of pycnidia.

Material examined: CHINA, Guangdong Province, Huazhou, isolated from a healthy fruit of C. grandis cv. "Tomentosa," May 2019, ZY Dong and YX Shu, (dried culture ZHKU 20-0011); living culture ZHKUCC 20-0011).

Habitat and host: Senna bicapsularis (Yang et al., 2017a).

Known distribution: China (Yang et al., 2017a).

Note: The ZHKUCC 20-0011 isolate obtained in this study clustered together with the D. sennae (CFCC 51636) with $95 \%$ maximum likelihood, 92\% maximum parsimony bootstrap, and 1.0 Bayesian posterior probability values. Morphologically the isolate in this study produces a similar size of alpha and beta conidia to the D. sennae type description (Yang et al., 2017a).
Gamma conidia were also observed in strain ZHKUCC 200011 of this study after 7 days on PDA. Diaporthe sennae was introduced by Yang et al. (2017a) as a species associated with dieback of Senna bicapsularis. This is the first record of D. sennae on C. grandis cv. "Tomentosa” (Farr and Rossman, 2020).

\section{DISCUSSION}

In the present study, Diaporthe species were isolated as endophytes from C. grandis cv. "Tomentosa" in China with 24 isolates from fruits, leaves, and twigs. Based on the multigene phylogeny, all 24 isolates from this study were grouped in 11 distinct clades within the Diaporthe phylogenetic tree. Among them, two species (D. arecae and D. biconispora) are already known to be associated with $C$. grandis. Nine new host records were identified namely: D. apiculata, D. aquatica, D. limonicola, D. masirevicii, D. passifloricola, D. perseae, and D. sennae. The remaining two species were identified as novel and introduced here as D. endocitricola, and D. guangdongensis. This study is the first comprehensive analysis of endophytic fungi associated with C. grandis in China.

The host species in this study is C. grandis cv. "Tomentosa," which is commonly known as "huajuhong" in China is a famous traditional Chinese medicinal plant, which has been used to alleviate cough and phlegm for several hundred years 
(Jiang et al., 2014). It has been proved that the endophytic fungi associated with medicinal plants have the ability to act as biological control agents (Carvalho et al., 2012) and some have anticancer activities (Carvalho et al., 2012). A few studies have revealed that secondary metabolites produced by endophytic fungi could be novel sources of medicinal compounds (Strobel et al., 2001; Kusari et al., 2012). Therefore, further studies are necessary to understand the relationship between medicinal properties and a plant's endophytic biota.

In the present study, endophytes were isolated from fruits, leaves, and twigs. Diaporthe masirevicii and D. passifloricola were isolated from fruits and twigs of C. grandis, while the other species were isolated from only one tissue type. A lower degree of colonization was observed on leaves (the only two species isolated were; Diaporthe perseae and Diaporthe biconispora). Similar to this study, Gond et al. (2007) and Huang et al. (2015) observed a lower number of endophytic species in leaves of Citrus spp. One endophytic species might occur in different tissues in the same host (Huang et al., 2015). However, the endophytic colonization in different tissues of the same plant might also vary (Taylor et al., 1999; Huang et al., 2015). For example, greater numbers of endophytic fungi were isolated from flowers and seeds than that from vegetative organs like stems and leaves (Braun et al., 2003). It has also been observed that greater numbers of endophytes could be isolated from veinal tissues than from interveinal tissues (Taylor et al., 1999). These variations might be a result of differences in the tissue organizational structure and the different nutrition content of each tissue type (Rana et al., 1997; Huang et al., 2015). However, the exact underlying reasons and mechanisms for these variations are not known. It is thus clear that further studies are needed to compare the variations in endophytic colonization according to different seasons or different stages of maturity of the plant.

Diaporthe biconispora was previously reported as an endophyte in branches of Citrus sinensis in China (Huang et al., 2015). In the present study, this species was isolated from leaves. Thus, D. biconispora may be a common endophytic species in Chinese Citrus plants. Diaporthe limonicola has been reported as pathogenic on Citrus sp. (Huang et al., 2015; Guarnaccia and Crous, 2017) and was first reported as a dieback pathogen of lemon trees in Europe. This species causes serious cankers on Citrus limon, C. aurantiifolia, C. reticulata, and C. sinensis (Guarnaccia and Crous, 2017). Identification of previously known pathogenic species as endophytes might reveal the opportunistic pathogenic nature of the Diaporthe species (Manawasinghe et al., 2019). Moreover, this is also important to develop quarantine measures to prevent the introduction of these species into new localities. Two of the species isolated in this study have been reported as pathogens on several other hosts. Diaporthe masirevicii has been reported causing peanut stem and peg dieback in Australia (Thompson et al., 2018), Gloriosa superba leaf blight in India (Naveen et al., 2018) and Physalis peruviana fruit rot in Brazil (Pazdiora et al., 2018). Diaporthe perseae was reported causing stem-end rot of mango (Lim et al., 2019). Therefore, further studies are necessary to understand the pathogenicity of these endophytic strains and the factors that determine their pathogenicity on Citrus.
In addition to previously known species from Citrus, in the present study, we identified nine novel host records and two new species. Novel species and host records are an indication of the ability of Diaporthe to evolve rapidly (Manawasinghe et al., 2019). Furthermore, this reflects the high species diversity of Diaporthe associated with a single host. Several studies have revealed the high species richness of Diaporthe species as endophytes on different hosts (Skaltsas et al., 2011; Rhoden et al., 2012). When there are diverse species associated with a single host, there is the potential of emerging new pathogens on Citrus. This could be a result of the species developing into taxa with greater virulence, or divergence of existing species into a novel species via long term exposure to natural and human-mediated factors. One possible phenomenon is the application of fungicides for other known phytopathogens while non-target fungal species become pathogenic a few years later. Thus, it might be challenging to control current disease while eliminating new disease occurrences. To overcome this, further studies are necessary to understand the interaction of endophytes with phytopathogenic genera and their effect on the Citrus microbiome.

\section{CONCLUSION}

In the present study, eleven endophytic Diaporthe species were isolated and identified from C. grandis cv. "Tomentosa" in China. Two new species D. endocitricola and D. guangdongensis were introduced. This study reveals the existence of several previously known pathogenic Diaporthe species as endophytes. Thus, it reflects the opportunistic nature of Diaporthe species as phytopathogens. However, further studies are necessary to understand the pathogenic potential of these endophytic taxa on C. grandis or other Citrus species in China. These results will open a discussion on interactions between fungal species on a particular host as endophytes, pathogens and potential biocontrol agents. In addition, these results will provide a platform to develop antimicrobial compounds, and to understand the contribution of endophytes to the medicinal values of the plant.

\section{DATA AVAILABILITY STATEMENT}

The datasets presented in this study can be found in online repositories. The names of the repository/repositories and accession number(s) can be found in the article/Supplementary Material.

\section{AUTHOR CONTRIBUTIONS}

ZD and ML conceived the research and planned the basic research. YS provided the materials. YS, YH, and ML conducted the experiments. $\mathrm{ZD}, \mathrm{ML}$, and IM prepared the manuscript. $\mathrm{ZD}, \mathrm{ML}, \mathrm{IM}$, and AP analyzed the data. AP, KH, AD, and MX revised the manuscript. All authors read and approved the final manuscript. 


\section{FUNDING}

This project was funded by the grant from the Key Realm R\&D Program of Guangdong Province (2018B020205003).

\section{ACKNOWLEDGMENTS}

We would like to thank Shaun Pennycook for the guidance for new species names. ZD would like to thank the Department of Science and Technology, Guangdong Province for funding the Key Realm R\&D Program of Guangdong Province (2018B020205003). KH thanks the Thailand Research grant

\section{REFERENCES}

Alvin, A., Miller, K. I., and Neilan, B. A. (2014). Exploring the potential of endophytes from medicinal plants as sources of antimycobacterial compounds. Microbiol. Res. 169, 483-495. doi: 10.1016/j.micres.2013. 12.009

Beraha, L., and O’Brien, M. J. (1979). Diaporthe melonis sp. nov., a New Soft Rot of Market Cantaloupes. Phytopath 94, 199-207. doi: 10.1111/j.1439-0434.1979. tb01551.x

Botella, L., and Diez, J. J. (2011). Phylogenic diversity of fungal endophytes in spanish stands of pinus halepensis. Fungal. Divers. 47, 9-18. doi: 10.1007/ s13225-010-0061-1

Braun, K., Romero, J., Liddell, C., and Creamer, R. (2003). Production of swainsonine by fungal endophytes of locoweed. Mycol. Res. 107, 980-988. doi: 10.1017/S095375620300813X

Carbone, I., and Kohn, L. (1999). A method for designing primer sets for speciation studies in filamentous ascomycetes. Mycologia 91, 553-556. doi: 10.2307/ 3761358

Carvalho, C. R., Gonalves, V. N., Pereira, C. B., Johann, S., Galliza, I. V., Alves, T. M. A., et al. (2012). The diversity, antimicrobial and anticancer activity of endophytic fungi associated with the medicinal plant Stryphnodendron adstringens (mart.) coville (fabaceae) from the brazilian savannah. Symbiosis 57, 95-107. doi: 10.1007/s13199-012-0182-2

Chomnunti, P., Schoch, C. L., Aguirre-Hudson, B., Ko-Ko, T. W., Hongsanan, S., Jones, E. B. G., et al. (2011). Capnodiaceae. Fungal. Divers. 51, 103-134. doi: 10.1007/s13225-011-0145-6

Crous, P. W., Verkley, G. J. M., Groenewald, J. Z., and Samson, R. A. (2009). Fungal Biodiversity. CBS Laboratory Manual Series 1. Utrecht, Netherlands: Westerdijk Fungal Biodiversity Institute.

Crous, P. W., Wingfield, M. J., Richardsom, D. M., Roux, J. J. L., Strasberg, D., Edwards, J., et al. (2016). Fungal Planet description sheets: 400-468. Persoonia 36, 316-458. doi: 10.3767/003158516X692185

Dini-Andreote, F. (2020). Endophytes: the second layer of plant defense. Trend. Plant Sci. 25, 319-322. doi: 10.1016/j.tplants.2020.01.007

Diogo, E. L. F., Santos, J. M., and Phillips, A. J. L. (2010). Phylogeny, morphology and pathogenicity of Diaporthe and Phomopsis species on almond in Portugal. Fungal Diver. 44, 107-115. doi: 10.1007/s13225-010-0057-x

Dissanayake, A. J., Liu, M., Zhang, W., Chen, Z., Udayanga, D., Chukeatirote, E., et al. (2015). Morphological and molecular characterisation of Diaporthe species associated with grapevine trunk disease in China. Fungal. Biol. 119, 283-294. doi: 10.1016/j.funbio.2014.11.003

Dissanayake, A. J., Zhang, W., Liu, M., Hyde, K. D., Zhao, W. S., Li, X. H., et al. (2017a). Diaporthe species associated with peach tree dieback in Hubei. China. Mycosphere 8, 533-549. doi: 10.5943/mycosphere/8/5/3

Dissanayake, A. J., Phillips, A. J. L., Hyde, K. D., Yan, J. Y., and Li, X. H. (2017b). The current status of species in Diaporthe. Mycosphere. 8, 1106-1156. doi: $10.5943 /$ mycosphere/8/5/5

Guarnaccia, V., Groenewald, J. Z., Woodhall, J., Armengol, J., Cinelli, T., Eichmeier, A., et al. (2018b). Diaporthe diversity and pathogenicity revealed from a broad survey of grapevine diseases in Europe. Persoonia-Mol. Phyl. Evol. Fungi 40, 135-153. doi: 10.3767/persoonia.2018.40.06 entitled Impact of climate change on fungal diversity and biogeography in the Greater Mekong Subregion (grant no: RDG6130001) for supporting this study. AP acknowledges the support from UIDB/04046/2020 and UIDP/04046/2020 Centre grants from FCT, Portugal (to BioISI).

\section{SUPPLEMENTARY MATERIAL}

The Supplementary Material for this article can be found online at: https://www.frontiersin.org/articles/10.3389/fmicb. 2020.609387/full\#supplementary-material

Du, Z., Fan, X. L., Hyde, K. D., Yang, Q., Liang, Y. M., and Tian, C. M. (2016). Phylogeny and morphology reveal two new species of Diaporthe form Betula spp. in China. Phytotaxa 269, 090-102. doi: 10.11646/phytotaxa.269.2.2

Fan, X. L., Yang, Q., Bezerra, J. D. P., Alvarez, L. V., and Tian, C. M. (2018). Diaporthe from walnut tree (Juglans regia) in China, with insight of the Diaporthe eres complex. Mycol. Pap. 17, 841-853. doi: 10.1007/s11557-0181395-4

Farr, D. F., and Rossman, A. Y. (2020). Fungal Databases, U.S. National Fungus Collections, ARS, USDA. Available Online at: https://nt.ars-grin.gov/ fungaldatabases/. Retrieved July 14, 2020.

Gao, Y., Liu, F., Duan, W., Crous, P. W., and Cai, L. (2017). Diaporthe is paraphyletic. Ima Fungus 8, 153-187. doi: 10.5598/imafungus.2017.08.01.11

Gao, Y. H., Liu, F., and Cai, L. (2016). Unravelling Diaporthe species associated with Camellia. Systematics and Biodiversity 14, 102-117. doi: 10.1080/14772000. 2015.1101027

Glass, N. L., and Donaldson, G. C. (1995). Development of primer sets designed for use with the PCR to amplify conserved genes from filamentous ascomycetes. Appl. Environ. Microbiol. 61, 1323-1330. doi: 10.0000/PMID7747954

Gomes, R. R., Glienke, C., Videira, S. I. R., Lombard, L., Groenewald, J. Z., and Crous, P. W. (2013). Diaporthe: a genus of endophytic, saprobic and plant pathogenic fungi. Persoonia 31, 1-41. doi: 10.3767/003158513X666844

Gond, S. K., Verma, V. C., Kumar, A., Kumar, V., and Kharwar, R. N. (2007). Study of endophytic fungal community from different parts of Aegle marmelos correae (rutaceae) from varanasi (india). World J. Microbiol. Biotechnol. 23, 1371-1375. doi: $10.1007 / \mathrm{s} 11274-007-9375-\mathrm{x}$

Guarnaccia, V., and Crous, P. W. (2017). Emerging citrus diseases in Europe caused by Diaporthe spp. IMA Fungus 8, 317-334. doi: 10.5598/imafungus.2017.08. 02.07

Guarnaccia, V., and Crous, P. W. (2018). Species of Diaporthe on Camellia and Citrus in the Azores Islands. Phytopathol. Medit. 57, 307-319. doi: 10.14601/ Phytopathol_Mediterr-23254

Hall, T. (2006). Bioedit. Raleigh, NC: Department of Microbiology, North Carolina State University. Available online at: http://www.mbio.ncsu.edu/BioEdit/page2. html

Hu, D. M., Cai, L., and Hyde, K. D. (2012). Three new ascomycetes from freshwater in China. Mycologia 104, 1478-1489. doi: 10.3852/11-430

Huang, F., Hou, X., Dewdney, M. M., Fu, Y. S., Chen, G. Q., Hyde, K. D., et al. (2013). Diaporthe species occurring on citrus in China. Fungal. Divers. 61 237-250. doi: 10.1007/s13225-013-0245-6

Huang, F., Udayanga, D., Wang, X. H., Hou, X., Mei, X. F., Fu, Y. S., et al. (2015) Endophytic Diaporthe associated with Citrus: a phylogenetic reassessment with seven new species from China. Fungal Biol. 119, 331-347. doi: 10.1016/j.funbio. 2015.02.006

Hyde, K. D., and Soytong, K. (2008). The fungal endophyte dilemma. Fungal. Divers. 33, 163-173.

Hyde, K. D., Tennakoon, D. S., Jeewon, R., Bhat, D. J., and Doilom, M. (2019). Fungal diversity notes 1036-1150: taxonomic and phylogenetic contributions on genera and species of fungal taxa. Fungal. Divers. 96, 1-242. doi: 10.1007/ s13225-019-00429-2

Jayasiri, S. C., Hyde, K. D., Ariyawansa, H. A., Bhat, J., Buyck, B., Cai, L., et al. (2015). The faces of fungi database: fungal names linked with morphology, 
molecular and human attributes. Fungal. Divers. 74, 3-18. doi: 10.1007/s13225015-0351-8

Jiang, K., Song, Q., Wang, L., Xie, T. Z., Wu, X., Wang, P. et al. (2014). Antitussive, expectorant and anti-inflammatory activities of different extracts from Exocarpium citri grandis. J. Ethnopharmacol. 156, 97-101. doi: 10.1016/j. jep.2014.08.030

Katoh, K., and Toh, H. (2010). Recent developments in the MAFFT multiple sequence alignment program. Brief. Bioinform. 9, 286-298. doi: 10.1093/bib/ bbn 013

Kishino, H., and Hasegawa, M. (1989). Evaluation of the maximum likelihood estimate of the evolutionary tree topologies from DNA sequence data. J. Mol. Evol. 29, 170-179. doi: 10.1007/BF02100115

Kusari, S., Hertweck, C., and Spiteller, M. (2012). Chemical ecology of endophytic fungi: origins of secondary metabolites. Chem. Biol. 19, 792-798. doi: 10.1016/ j.chembiol.2012.06.004

Lim, L., Mohd, M. H., and Zakaria, L. (2019). Identification and pathogenicity of Diaporthe species associated with stem-end rot of mango (Mangifera indica L.). Eur. J. Pl. Pathol. 155, 687-696. doi: 10.1007/s10658-019-01 800-4

Long, H., Zhang, Q., Hao, Y. Y., Shao, X. Q., Wei, X. X., Hyde, K. D., et al. (2019). Diaporthe species in south-western China. MycoKeys 57, 113-127. doi: 10.3897/mycokeys.57.35448

Manawasinghe, I. S., Dissanayake, A. J., Li, X., Liu, M., Wanasinghe, D. N., Xu, J., et al. (2019). High genetic diversity and species complexity of diaporthe associated with grapevine dieback in China. Front. Microbiol. 10:1936. doi: 10.3389/fmicb.2019.01936

Miller, M. A., Pfeiffer, W., and Schwartz, T. (2010). "Creating the CIPRES Science Gateway for inference of large phylogenetic trees, in Proceedings of the Gateway Computing Environments Workshop (GCE) 14 Nov 2010. New Orleans, LA: Institute of Electrical and Electronics Engineers.

Mondal, S. N., Vicent, A., Reis, R. F., and Timmer, L. W. (2007). Saprophytic colonization of citrus twigs by Diaporthe citri and factors affecting pycnidial production and conidial survival. Plant Dis. 91: 387-392. doi: 10.1094/pdis-914-0387

Murali, T., Suryanarayanan, T., and Geeta, R. (2006). Endophytic Phomopsis species: host range and implications for diversity estimates. Can. J. Microbiol. 52, 673-680. doi: 10.1139/w06-020

Naveen, J., Navya, H. M., Hithamani, G., Niranjana, S. R., and Hariprasad, P. (2018). First report of Diaporthe masirevicii causing leaf blight of Gloriosa superba in India. New Dis. Rep. 37:13. doi: 10.5197/j.2044-0588.2018. 037.013

Nitschke, T. (1870). Pyrenomycetes Germanici 2, 161-320 Breslau. Germany: Eduard Trewendt.

Nylander, J. A. A. (2004). MrModeltest 2.0. Program distributed by the author. Uppsala, Sweden: Evolutionary Biology Centre Uppsala University.

Pazdiora, P. C., Hoffmann, J. F., Chaves, F. C., and Dallagnol, L. J. (2018). First report of fruit rot caused by Diaporthe masirevicii on Physalis peruviana in Brazil. Pl. Dis. 102, 441-442. doi: 10.1094/PDIS-06-17-0874-PDN

Rana, B. K., Singh, U. P., and Taneja, D. (1997). Antifungal activity and kinetics of inhibition by essential oil isolated from leaves of Aegle marmelos. J. Ethnopharmacol. 57, 29-34. doi: 10.1016/S0378-8741(97)00 044-5

Rayner, R. W. (1970). A mycological colour chart. Kew, UK: Commonwealth Mycological Institute.

Rhoden, S. A., Garcia, A., Filho, C. J. R., Azevedo, J. L., and Pamphile, J. A. (2012). Phylogenetic diversity of endophytic leaf fungus isolates from the medicinal tree Trichilia elegans (meliaceae). Genet. Mol. Res. 11, 2513-2522. doi: 10.4238/2012. June.15.8

Ronquist, F., and Huelsenbeck, J. P. (2003). MrBayes 3: Bayesian phylogenetic inference under mixed models. Bioinformatics 19, 1572-1574. doi: 10.1093/ bioinformatics/btg180

Rossman, A., Udayanga, D., Castlebury, L., and Hyde, K. (2014). (2304) proposal to conserve the name Diaporthe eres against twenty-one competing names (Ascomycota: Diaporthales: Diaporthaceae). Taxon 63, 934-935. doi: 10.12705/ 634.23

Santos, J. M., and Phillips, A. J. L. (2009). Resolving the complex of Diaporthe (Phomopsis) species occurring on Foeniculum vulgare in Portugal. Fungal. Divers. 34, 111-125. doi: 10.1002/yea. 1657
Santos, L., Alves, A., and Alves, R. (2017). Evaluating multi-locus phylogenies for species boundaries determination in the genus Diaporthe. Peer J. 5:3120. doi: $10.7717 /$ peerj. 3120

Senanayake, I. C., Crous, P. W., Groenewald, J. Z., Maharachchikumbura, S. S., Jeewon, R., Phillips, A. J. L., et al. (2017). Families of Diaporthales based on morphological and phylogenetic evidence. Stud. Mycol. 86, 217-296. doi: 10. 1016/j.simyco.2017.07.003

Silvestro, D., and Michalak, I. (2010). RaxmlGUI: a Graphical Front-End for RAxML. Available Online at: http://sourceforgenet/projects/raxmlgui/ (accessed February 25, 2019)

Skaltsas, D., Castlebury, L., and Chaverri, P. (2011). Delimitation of tropical endophytic Phomopsis species from three euphorbiaceous hosts: Hevea brasiliensis, H. guianensis, and Micandra sp. Inoculum 62:41.

Smith, H., Wingfield, M. J., Crous, P. W., and Coutinho, T. A. (1996). Sphaeropsis sapinea and Botryosphaeria dothidea endophytic in Pinus spp. and Eucalyptus spp. in South Africa. S. Afr. J. Bot. 62, 86-88. doi: 10.1016/s0254-6299(15) 30596-2

Stamatakis, A. (2014). RAxML version 8: a tool for phylogenetic analysis and post-analysis of large phylogenies. Bioinformatics 30, 1312-1313. doi: 10.1093/ bioinformatics/btu033

Strobel, G. A., Dirkse, E., Sears, J., and Markworth, C. (2001). Volatile antimicrobials from Muscodor albus a novel endophytic fungus. Microbiology 147, 2943-2950.

Sun, L. F., Zhang, Y. H., and Pei, K. Q. (2009). A rapid extraction of genomic DNA from fungi. Mycosystema 28, 299-302.

Swofford, D. L. (2003). PAUP: Phylogenetic Analysis Using Parsimony and Other Methods, Version 4. Sunderland, Massachusetts: Sinauer Associates.

Taylor, J. E., Hyde, K. D., and Jones, E. B. G. (1999). Endophytic fungi associated with the temperate palm, Trachycarpus fortunei, within and outside its natural geographic range. New Phytologist. 142, 335-346. doi: 10.1046/j.1469-8137. 1999.00391.x

Thompson, S., Tan, Y., Young, A., Neate, S., Aitken, E., and Shivas, R. (2011). Stem cankers on sunflower (Helianthus annuus) in Australia reveal a complex of pathogenic Diaporthe (Phomopsis) species. Persoonia 27, 80-89. doi: 10.3767/ 003158511 X617110

Thompson, S. M., Grams, R. A., Neate, S. M., Shivas, R. G., Ryley, M. J., Tan, Y. P., et al. (2018). First reports of Diaporthe kongii, D. masirevicii, and D. ueckerae associated with stem and peg dieback on peanut in Australia. Pl. Dis. 102:1459. doi: 10.1094/PDIS-12-17-1930-PDN

Thompson, S. M., Tan, Y. P., Shivas, R. G., Neate, S. M., Morin, L., Bissett, A., et al. (2015). Green and brown bridges between weeds and crops reveal novel Diaporthe species in Australia. Persoonia 35, 39-49. doi: 10.3767/ 003158515 X687506

Turkkan, M., Kilicoglu, M. C., and Erper, I. (2020). Characterization and pathogenicity of Rhizoctonia isolates collected from Brassica oleracea var. acephala in Ordu, Turkey. Phytoparasitica 48, 273-286.

Udayanga, D., Castlebury, L. A., Rossman, A. Y., Chukeatirote, E., and Hyde, K. D. (2014a). Insights into the genus Diaporthe: phylogenetic species delimitation in the D. eres species complex. Fungal. Divers. 67, 203-229. doi: 10.1007/s13225014-0297-2

Udayanga, D., Castlebury, L. A., Rossman, A. Y., and Hyde, K. D. (2014b). Species limits in Diaporthe: molecular re-assessment of D. citri, D. cytosporella, D. foeniculina and D. rudis. Persoonia 32, 83-101. doi: 10.3767/003158514X679984

Udayanga, D., Liu, X. Z., Crous, P. W., McKenzie, E. H. C., Chukeatirote, E., Hyde, K. D. et al. (2012). A multi-locus phylogenetic evaluation of Diaporthe (Phomopsis). Fungal. Divers. 56, 157-171. doi: 10.1007/s13225-012-0190-9

Udayanga, D., Liu, X. Z., McKenzie, E. H. C., Chukeatirote, E., Bahkali, A. H. A., Hyde, K. D. et al. (2011). The genus Phomopsis: biology, applications, species concepts and names of common phytopathogens. Fungal. Divers. 50, 189-225. doi: 10.1007/s13225-011-0126-9

White, T., Bruns, T., Lee, S., and Taylor, J. (1990). “Amplification and direct sequencing of fungal ribosomal RNA genes for phylogenetics," in PCR protocols, a guide to methods and applications, eds M. A. Innis, D. H. Gelfand, J. J. Sninsky, and T. J. White (New York: Academic Press), 315-322.

Yang, Q., Du, Z., and Tian, C. M. (2018a). Phylogeny and morphology reveal two new species of Diaporthe from traditional chinese medicine in northeast china. Phytotaxa 336, 159-170. doi: 10.11646/phytotaxa.336.2.3 
Yang, Q., Fan, X. L., Guarnaccia, V., and Tian, C. M. (2018b). High diversity of Diaporthe species associated with dieback diseases in China, with twelve new species described. MycoKeys 39, 97-149. doi: 10.3897/mycokeys.39.26914

Yang, Q., Fan, X. L., Du, Z., and Tian, C. M. (2017a). Diaporthe species occurring on Senna bicapsularis in southern China, with descriptions of two species. Phytotaxa 302, 145-155. doi: 10.11646/phytotaxa.302.2.4

Yang, Q., Fan, X. L., Du, Z., Liang, Y. M., and Tian, C. M. (2017b). Diaporthe camptothecicola sp. nov. on Camptotheca acuminata in China. Mycotaxon 132, 591-601. doi: 10.5248/132.591

Yang, Q., Jiang, N., and Tian, C. M. (2020). Three new Diaporthe species from shanxi province, china. MycoKeys 67, 1-18. doi: 10.3897/mycokeys.67.49483
Conflict of Interest: The authors declare that the research was conducted in the absence of any commercial or financial relationships that could be construed as a potential conflict of interest.

Copyright (c) 2021 Dong, Manawasinghe, Huang, Shu, Phillips, Dissanayake, Hyde, Xiang and Luo. This is an open-access article distributed under the terms of the Creative Commons Attribution License (CC BY). The use, distribution or reproduction in other forums is permitted, provided the original author(s) and the copyright owner(s) are credited and that the original publication in this journal is cited, in accordance with accepted academic practice. No use, distribution or reproduction is permitted which does not comply with these terms. 